\title{
Fragmented Networks and Entrepreneurship in Late Imperial Russia ${ }^{1}$
}

\author{
Henning Hillmann \\ University of Mannheim \\ Brandy L. Aven \\ Carnegie Mellon University
}

\begin{abstract}
Emergent economies suffer from underdeveloped market infrastructures and insufficient public institutions to enforce contract commitments and property rights. Informal reputation-based arrangements may substitute for government enforcement, but they require close-knit networks that enable monitoring. Economic development also requires access to capital, information, and other resources, which is enabled by wide-reaching and diverse networks and not by closure. How is entrepreneurship possible given these conflicting demands? In this article, the authors examine how partnership networks and reputation channel the mobilization of capital for new enterprises, using quantitative information on 4,172 corporate partnerships during the industrialization of late imperial Russia (18691913). They find that reputation is locally effective in small and homogeneous network components. By contrast, founders in the largest components that form the network core raise more capital from investors but benefit less from reputation and more from brokerage opportunities and ties that reach diverse communities.
\end{abstract}

A central role of the state is the provision of stable institutions that ensure property rights, enforce contracts, and minimize transaction costs. Historical evidence supports this view of the economic role of the state and shows that

\footnotetext{
${ }^{1}$ We are particularly grateful to Rodrigo Canales, Christina Gathmann, Steve Nafziger, and Kate Stovel for their extensive comments and suggestions. We also wish to thank Josef Brüderl, Frank Dobbin, Roberto Fernandez, Neil Fligstein, Heather Haveman, Doug McAdam, Jim Moody, Aldo Musacchio, Susan Olzack, Woody Powell, Denis Trapido, Andy Walder, Ezra Zuckerman, the AJS reviewers, and seminar participants at the University of California, Berkeley, the University of Chicago, Harvard University, the University of Mannheim, Massachusetts Institute of Technology, Stanford University,
} 
reliable market-supporting institutions are vital to economic development. The challenge for emerging and transition economies is that they often suffer from insufficiently developed and unreliable public institutions that do not support economic transactions (North 1981; Haber, Razo, and Maurer 2003; Mokyr 2009). How, then, is economic development, and entrepreneurship in particular, possible in the absence of strong public institutions? Recent studies suggest that privately organized substitutes may emerge in settings where the public provision of adequate institutional scaffolding for economic activity fails. Such informal substitutes depend on information and trust within reputation-based networks. For example, medieval Maghribi traders formed a coalition based on their close-knit ethnic networks to monitor and sanction the agents they employed in overseas ports (Greif 2006). Agents who were found to have embezzled goods or proceeds for their own gain were ostracized by the entire coalition of traders and lost their reputation as reliable agents. Such enforcement through reputation works as long as agents value the longterm benefits of their reputation more than the short-term gains from embezzlement. Similar arrangements include the reliance on collective reputation among loan-seeking firms during Mexico's modern industrialization (Maurer and Sharma 2001), the enforcement of communal norms among neighboring farmers to contain potential conflicts arising from cattle trespassing in presentday rural California (Ellickson 1991), and trust-based business networks to cope with information asymmetries in developing markets in Africa (Fafchamps 2004).

Various definitions of reputation exist in the extant literature (Stuart, Hoang, and Hybels 1999; Podolny 2005; Greif 2006). Differences in detail aside, most social scientists agree upon two aspects of reputation: first, knowing a business partner's past behavior mitigates uncertainty about his future performance; second, reputation demonstrates the person's credibility as an honest business partner and reduces the uncertainty associated with trusting him. The first aspect considers reputation as an individual-level signal that potential partners and investors rely on to assess an entrepreneur's abilities and qualities. The second aspect points to collective reputation mechanisms that a community of merchants relies on to monitor and sanction opportunistic behavior. The individual and collective uses of reputation are closely linked, and we will explore both.

We argue that the composition of social structures-and not just the positions and strategies of individual entrepreneurs-that underpinned such reputation mechanisms was key to their success in encouraging en-

and Utrecht University for their helpful critiques. For all remaining errors, we alone are responsible. Stan Markuze contributed invaluable research assistance. Direct correspondence to Henning Hillmann, Department of Sociology, School of Social Sciences, University of Mannheim, D-68131 Mannheim, Germany. E-mail: hillmann@uni-mannheim.de 
trepreneurship. While context-specific variation in reputation-based institutions exists, they typically hinge on network closure because it enables local monitoring. Closure in social structure implies that an entrepreneur's contacts are also linked with each other. Close bonds within a community of merchant entrepreneurs ensure that members know how their exchange partners behaved in the past, whether the behavior complied with community norms or not, and if these partners should be trusted in future transactions (Coleman 1990; Burt 2005). Yet, emergent economies and transition societies tend to suffer both from the absence of reliable government institutions and from fragmentation into diverse and often opposing interest groups (Weingast 1997). Affiliations that may bridge the divisions rarely exist. Because reputation-based monitoring mechanisms rest on closure in local networks, their benefits as substitutes for missing public institutions may work well in local communities but do not extend beyond their boundaries. And because closure keeps knowledge and resources within local communities, it alone will not promote economic development — but it does facilitate strategies for staying in business and maintaining the economic status quo.

The creation of informal arrangements for coordination and monitoring may be adequate local responses to the lack of strong public institutions. Yet, to advance economic development, a different pattern of social networks is required. Collecting novel information, securing credit, and attracting capital from potential partners and investors are all essential for entrepreneurship and development in emergent economic settings (Fafchamps 2004). Development beyond the economic status quo mandates social structures that span diverse communities of entrepreneurs. Local closure is the opposite of network reach and hinders such allocation of resources. By contrast, wide-spanning networks foster economic development because they encourage brokerage between diverse social circles and open access to the resources, valuable opportunities, and novel information that lie beyond local closure and would otherwise be inaccessible to entrepreneurs (Burt 2005). ${ }^{2}$

To summarize our theoretical discussion so far, we argue that the social organizational demands of private-order institutions reveal a dilemma that is particularly salient for societies in transition as they struggle to overcome their economic backwardness, understood here as an insufficient ability or willingness of governments to maintain reliable market-supporting institutions as public goods (Haber et al. 2003). Because their public institutions

\footnotetext{
${ }^{2}$ Again, what distinguishes our argument from otherwise similar approaches (e.g., Burt 2005 ) is that we emphasize the potential of different network structures as foundations for private-order responses to the absence of reliable public institutions and not just their strategic options for individual entrepreneurs.
} 
are insufficiently developed, emergent economies should be prime candidates for the creation of privately organized alternatives. And yet their challenge is that the network alternatives-closure and reach-compete with each other. Their entrepreneurs face the double bind of either partnering within their tight-knit enclaves to ensure social control and reduce risk or partnering across social boundaries to expand capital access but making themselves potentially vulnerable to opportunism.

If these arguments are correct, then which of the alternative strategies will be more successful for teams of entrepreneurs to pursue will depend on the particular opportunity structure they are embedded in. Because the reliance on reputation mechanisms for monitoring rests on local closure, we would expect that reputation-based strategies of entrepreneurship are most successful in densely knit local networks and that they would be less salient in large cohesive networks that span across a variety of diverse clusters. Because network closure primarily contributes to the economic status quo, we would also expect that new ventures are more successful in attracting capital and other critical resources when they operate in more wide-spanning networks that are populated by entrepreneurs coming from diverse origins. These expectations delineate the possibilities and limitations of private-order arrangements to effectively support economic activities within the fragmented networks that tend to characterize emergent societies.

We consider the general question of economic development and entrepreneurship in the absence of strong institutions in the historical setting of corporate industrialization in late imperial Russia from 1869 to 1913. The period marked a profound transition for Russian economic development, leading from the Great Reforms, including the emancipation of enserfed peasants, to the Great War in 1913, which brought both the tsarist empire and corporate capitalism in Russia to an end. During this period, key corporate sectors, such as the railway, textile, and metallurgy industries, experienced rapid economic growth, but at the same time they had to confront glaring constitutional deficiencies that undermined the effective organization of corporate capitalism (Crisp 1976; Gregory 1994). Particularly consequential impediments to industrial development included arbitrary government decisions in economic policy, discrimination of Jewish entrepreneurs and other ethnic minorities, and unreliable enforcement of property rights (Owen 1991a, 2005; Gatrell 1995). The economic constraints coupled with ethnic, religious, and regional rivalries among the various merchant-industrialist factions (Rieber 1982; Joffe 1984; Clowes, Kassow, and West 1991). Within this setting, we focus on the founding of the large corporations that were primarily responsible for Russia's industrialization (large joint-stock companies and industrial partnerships accounted for $75 \%$ of the total corporate capital invested in 
companies in 1900 and for $86 \%$ in 1914; see Crisp 1976). We examine how corporate founders relied on their reputation and their networks of business partnerships to mobilize the necessary capital for new ventures. Supporting empirical evidence for our theoretical argument comes from our analysis of the founding activities of some 11,545 elite entrepreneurs connected through the networks of their partnerships in 4,172 chartered firms known to have operated in the period 1869-1913.

Three central results emerge from our study. First, the Russian corporate network was indeed fragmented into a widespread and well-connected core and a periphery that consisted of hundreds of scattered small components without any relational bridges connecting them. Local network closure characterized the small components in the periphery, whereas far-reaching connections and brokerage opportunities characterized the core. Notably, the extent of network fragmentation changed little over the 1869-1913 period.

Second, homophily based on common ethnicity, regional origins, and shared experience in similar industries guided the composition of founding teams within the isolated and tight-knit clusters in the periphery. In contrast, the network core embedded entrepreneurs who came from more diverse ethnic and regional backgrounds and who invested in diverse industrial sectors. Likewise, the division between core and periphery in the corporate network did not map directly onto the economic and political geography of the Russian empire but instead crosscut geographic locations and their ethnic and socioeconomic boundaries. ${ }^{3}$

We are less interested in answering where the network fragmentation comes from. ${ }^{4}$ Instead, we seek to understand how different network patterns influence the mobilization of resources and capital for the founding of new ventures. We find, third, that cooperation with founding partners who have earned a reputation of successful entrepreneurship in the past did indeed raise the amount of capital mobilized for present ventures. More important, the effect of reputation on capital mobilization was significantly greater within the small and more homogenous components of founders in the periphery than within the network core. But founding partnerships in the core benefited from their opportunities for brokerage between diverse groups of enterprising merchants: on average, ventures

\footnotetext{
${ }^{3}$ Unless noted otherwise, whenever we use the terms "core" and "periphery," we refer to network analytic concepts and not to locations in the Russian industrial or political geography.

${ }^{4}$ The lack of adequate data means that an investigation of the origins of entrepreneurial networks in our historical case is beyond the scope of this article. Recent work on network formation in general, and the origins of homophily in particular, suggests an endogenous relationship between people's preferences and network structure: their preferences lead people to particular positions and exchange partners just as much as their existing networks shape those preferences (Kossinets and Watts 2009; Wimmer and Lewis 2010).
} 
in the wide-spanning network core attracted significantly more capital than ventures in the periphery.

The contribution of the present study is twofold. First, and substantively, our finding that the corporate network, and especially its core, did not correspond to Russia's industrial and political geography suggests that economic partnerships may have served as alternative affiliations that bridged the political and regional divisions in the multiethnic Russian empire. Second, our historical case also offers a more general lesson for understanding how cooperation through private-order arrangements may support entrepreneurship in the absence of reliable government institutions. The mere availability of privately organized substitutes for public institutions will not be sufficient. Whether their support will be successful or not depends on the particular composition of the opportunity structure within which entrepreneurs find themselves. Closure in the relationships among entrepreneurs facilitates collective monitoring through reputation costs, but its scope is unlikely to extend beyond local communities. However, access to information, capital, credit, and other valuable resources necessitates wide-spanning relationships that reach diverse communities of merchant entrepreneurs.

\section{HISTORICAL SETTING}

On the eve of the Great War in 1913, Russia ranked as the fifth largest industrial power, on par with Austria-Hungary and following behind the United States, the United Kingdom, France, and Germany. Between 1885 and 1913, Russia's average annual growth rate of total product (3.25\%) was exceeded only by the United States, Canada, Australia (all three experiencing significant in-migration in contrast to Russia's out-migration), Japan, and Sweden. Where Russia lagged behind its competitors was in its economic performance on a per capita basis. At 101.4 rubles per capita, Russia's gross national product (GNP) in 1913 compared unfavorably with Germany's 300.4 rubles, the United Kingdom's 460.6 rubles, and the United States' 682.2 rubles. One important reason was that output growth combined with exceptionally rapid population growth (Gregory 1994). The population within the Russian empire increased by nearly $140 \%$, from 74.1 million in 1860 to 175.1 million in 1914, the most rapid population growth in Europe. The average rate of urbanization in the provinces of European Russia increased little, from 9.9\% in 1863 to merely $14.4 \%$ in 1914 (Crisp 1976). The share of agriculture relative to industrial production reflects the lasting rural concentration. Russia remained the world's largest grain producer in the period 1861-1913, but it was a minor producer of industrial commodities. Although $75 \%$ of its 
labor force was engaged in agriculture, the grain output per capita was well below the output of France, Germany, and the United States and roughly equal to that of Austria-Hungary. Russia's per capita output in industrial products was only half of Austria-Hungary's in 1913 (Gregory 1994).

Few historians would deny the central role the state played in Russia's economic development. The ability to maintain market-supporting institutions and policies is arguably the main economic reason why states exist (North 1981). In Russia's case, the historical evidence indicates that, after the defeat in the Crimean War (1853-56) and an ensuing economic stagnation, the tsarist regime was forced to adopt social reforms and industrial modernization if it wanted to live up to its ambitions of great power status (Gatrell 1986; Eklof, Bushnell, and Zakharova 1994). Earlier work, such as Gerschenkron's (1962), characterized the ambitions of an active Russian state that was eager to close the economic gap separating it from competing countries: "Economic development in a backward country such as Russia can be viewed as a series of attempts to find-or to createsubstitutes for those factors which in more advanced countries had substantially facilitated economic development, but which were lacking in conditions of Russian backwardness" (Gerschenkron 1962, p. 123). Gerschenkron argued that the tsarist state was particularly successful in its interventions in two key areas of industrialization. One area was the attraction of foreign entrepreneurial expertise and capital, which was aided by the introduction of a stable gold-backed currency whose absence before 1897 Gerschenkron regarded as one of the important reasons for Russia's belated industrialization. The other area concerned the role of the state as a substitute entrepreneur. To promote industrialization, according to Gerschenkron's argument, the tsarist government erected tariff barriers for imported commodities, expanded railroad construction, subsidized private enterprise, and reserved contracts for military equipment for domestic firms.

More recent explorations in economic history find less empirical support for Gerschenkron's positive view of the state in Russia's economic development (Gatrell 1986; Gregory 1994; Owen 2005). Kahan (1989, p. 96) shows that the government spent "only a minute part of its budget expenditures . . . for purposes of developing the industrial sector." The evidence also indicates that tsarist tariff policies were motivated as much by fiscal needs as by aims to protect domestic industries, as Gerschenkron implied (Kahan 1989). Others have also challenged Gerschenkron's positive interpretation of the state's policy toward foreign investment and the promotion of entrepreneurship. McKay (1970) and Carstensen (1983, 1984) demonstrate that expectations of high returns in an emerging mass market attracted foreign investors more than skillful campaigns of Rus- 
sian government officials. Few would therefore question the inflow of foreign investment. ${ }^{5}$ But, as documented by Owen $(1991 a, 2005)$ and others (Crisp 1976; Gatrell 1995), industrialists repeatedly complained that the tsarist state failed to guarantee and enforce property rights. Instead of implementing policies that supported entrepreneurship, the tsarist administration undermined it through often arbitrary legislation. ${ }^{6}$

In a 1899 memorandum, even Minister of Finance Sergei Witte lamented how bureaucratic idiosyncrasies strangled foreign investments: "All foreign companies are subject to Russian laws and regulations as well as ordinances and rules which may be subsequently issued. In permitting the activities of foreign companies in Russia, the government retains the right to revoke at any time that permission and to demand the liquidation of any company. Obviously, every detail of the influx of foreign capital into Russia is kept under strictest control by the central and local authorities" (quoted in Von Laue 1963, p. 181). Such hindrances to property rights were not limited to foreign investors. An 1899 Ministry of Finance memorandum reveals that preventing "the encroachment of undesirable elements" was the motivation behind increasingly severe measures to limit the rights to property, residence, and managerial functions of Jewish entrepreneurs (cited in Owen 1991a, p. 122; see Rogger 1986; Nathans 2002). Even ethnic Russian entrepreneurs like Moscow merchant F. V. Chizhov deplored the "stupidity, conceit, and ignorance of the army of pen-pushers" in the imperial bureaucracy and their arbitrary governance (quoted in Rieber 1982, p. 176). Just as their Jewish business partners elsewhere, leading Muscovite merchants faced persecution simply because they did not adhere to the Orthodox Church but to the sectarian Old Belief. They had to confront corrupt and inefficient government officials, disruptive labor policies, and police controls. They risked arrest for advocating their radical slavophile politics and their opposition to the

\footnotetext{
${ }^{5}$ McKay (1970, pp. 25-29) reports that foreign ownership of common stock in industrial corporations increased from $17 \%$ in 1880 to $47 \%$ in 1914 and that foreign investments accounted for $55 \%$ of new capital in $1893-1900$ and for 50\% in 1909-13 (see also Carstensen 1983).

${ }^{6}$ The state prohibited foreigners from owning shares or holding managerial positions in the trade and shipping industry on the Caspian Sea (law of November 1869); Siberian gold mining was restricted to ethnic Russians (law of January 1885); the law of March 1887 prohibited foreign companies from owning or leasing rural land in Poland, the eight western Russian provinces, Bessarabia, Courland, and Livonia; if Russian companies held land in these areas, foreigners could not own shares; the law of December 1888 prohibited foreigners from acquiring land for mining in Poland; corporations with Jewish or foreign stockholders could not purchase real estate in Turkistan (law of November 1893); the law of June 1899 closed managerial positions to foreigners in the western provinces, Don military region, Caucasus, Turkestan, and Amur region (Owen 1991a, chap. 5).
} 
detested Petersburg bureaucrats (Rieber 1982). By 1913, property rights were still not fully enforced against government violations. In a State Duma speech during the same year, Aleksandr Konovalov, a textile magnate and prominent member of the progressive liberal party, demanded "to replace the 'arbitrariness of the administrative authorities with the creation of firm norms of legality ... . equal for all' and to eliminate 'red tape and tutelage' from the administration of corporate enterprise" (quoted in Owen 1991a, p. 169). Such was the broader institutional setting and economic climate within which Russian and foreign entrepreneurs pursued their enterprises. It combined a merchantry weakened by fragmentation into competing interest groups, unreliable political institutions, and economic growth that was often hindered by poorly formulated commercial policies of the imperial administration.

\section{DATA SOURCES}

Supporting evidence for our arguments comes from the RUSCORP database (Owen 1992). It contains rich quantitative information on the nature of all for-profit corporations founded in the Russian empire from the time of Peter the Great to the Great War. To examine entrepreneurship in late imperial Russia, we use the information on the company profiles of share partnerships and joint-stock companies recorded in their corporate charters. Russian corporate law distinguished the large corporation and the share partnership from the small business and trading firm (torgovyi dom) that only required a contract, signed by all partners and registered with the local municipal clerk (Owen 1991a). The RUSCORP data set does not include the various midlevel trading firms and small family businesses because they did not require an imperial charter. ${ }^{7}$

Our empirical focus on large corporations and partnerships implies that we are considering the pursuits of the business elite. One reason for focusing on elites is that we are also interested in the political consequences of the merchants' economic activities, and the extant literature recognizes that the merchant elite carried most of the political weight in the Russian business community (Rieber 1982; Owen 2005). Within this empirical scope, we consider all incorporations from the late 1860s to the eve of

\footnotetext{
${ }^{7}$ However, Owen (1991a, p. 11) suggests that "their aggregate economic importance remained minor." He notes that despite the large number of over 9,000 small trading firms in 1914, their entire basic capital stock of 333.1 million rubles was dwarfed by the stock value of 4.6 billion rubles of the 2,263 industrial corporations in the same year. Further, corporations accounted for $74 \%$ (in 1900) and $86 \%$ (in 1914) of the capital invested in industrial and commercial companies (Crisp 1976, p. 113). Moreover, small partnership firms typically existed only for short periods because changes in partners required the dissolution of the firm and a new contract (Owen 1992, p. 20).
} 
the Great War in 1913, a crucial transition period for Russian economic development that witnessed the consequences of the Great Reforms under Alexander II, an unprecedented rise of heavy industry and the inflow of foreign investment (McKay 1970; Carstensen 1983, 1984; Eklof et al. 1994). Figure 1 illustrates the rise in the number of corporate foundings in the Russian empire during the 1869-1913 period. $^{8}$

The founding of both forms of large corporations, the share partnership (tovarishchestvo na paiakh) and the joint-stock company (aktsionernoe obshchestvo), required the approval of the central government, which granted charters only to enterprises that it deemed to be of national economic importance. All corporate charters had to be signed by the tsar. Members of the merchant guilds or any free estate could participate, and all members of a corporation enjoyed the privilege of limited liability (Owen 1991a). ${ }^{9}$ The corporate law of 1836 regulated incorporation. It introduced the concession system, which required every proposed founding charter to be reviewed by the appropriate ministry and state council before being signed by the tsar. To attract entrepreneurs and their capital, the ministerial review could also entail the granting of monopoly rights, tax exemptions, and other privileges if the ministers saw great significance in the proposed enterprise. Other articles exemplified the regulative nature of the government's policies: primarily to limit stock-jobbing and speculation, no company could start its operations before all shares were sold and payments collected; unnamed shares and futures were banned; founders could become members of the board but could not purchase more than one-fifth of the total share capital; and the annual general assembly of stockholders exercised the primary authority, including the election of the board, the general strategy, and the decision to dissolve the company. Once confirmed by the tsar's signature, the rules set forth in the founding charter could not be changed without the permission of the appropriate government authorities. With few exceptions, these legal regulations remained in place unaltered until the end of the tsarist regime (Owen 1991a).

\footnotetext{
${ }^{8}$ We start our periodization in 1869 because reliable price indices for deflating basic capital are not available for earlier years.

${ }^{9}$ Entrepreneurs in Saint Petersburg favored joint-stock companies. Typically, a large number of shares at small individual values was issued to raise basic capital for large projects such as railroads, steamship lines, or banks. Muscovite merchants preferred share partnerships, which typically entailed more intimate and family-business relationships and were established to provide limited liability for smaller ventures than the large joint-stock enterprises. Partnerships issued fewer shares at much higher values $(5,000-$ 10,000 rubles per share) compared to joint-stock companies (Crisp 1976; Owen 1991a).
} 


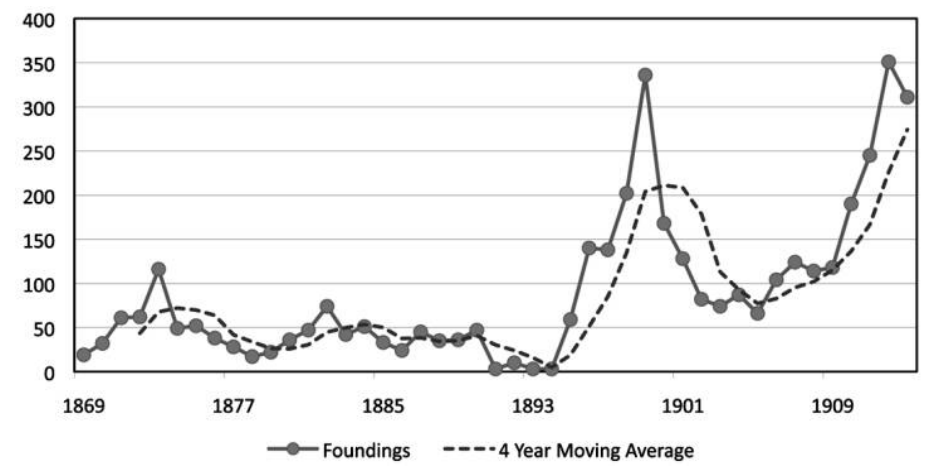

FIG. 1.-Number of corporate foundings within the Russian empire, 1869-1913

\section{Company Data}

Our outcome variable of interest is the amount of basic capital raised by a company's founders and recorded in its corporate charter. The basic capital recorded in the charter is best interpreted as a potential for attracting financial commitments from investors. But the critical point here is that a company could not start its operations before all shares were sold and payments collected. As the kind of ruble-silver, copper, or paper assignat - and the values of shares routinely varied from charter to charter, even within the same year, all capital values are normalized according to the standard ruble of account (Owen 1992). We then deflated all capital values using the standard Saint Petersburg Institute of Economic Research retail price index (Strumilin 1966; Gregory 1982). All capital values are denoted in thousands of rubles with 1913 as the base year. Where basic capital consisted of both stocks and bonds, the sum of both amounts is used. Table 1 reports descriptive statistics for this and all other company-level variables we use in our analysis.

\section{Founder Data}

The advantage of the data set for examining entrepreneurship is that it provides matching information on the characteristics of individual founders (to the extent that they are documented in the corporate charters or can be unambiguously established from secondary sources). In table 2, we compare summary statistics for the amount of basic capital and ethnic and social status background for founders who participated in no more than one corporate founding ( $n=8,709$, cols. $1-3)$ and serial entrepreneurs ( $n=768$, cols. 4-6) involved in the founding of several enterprises. The panel data yield multiple observations for serial entrepreneurs as they 
TABLE 1

CORPORATION CHARACTERISTICS, I869-I9I3

\begin{tabular}{|c|c|c|c|}
\hline & $\begin{array}{l}\text { Observations } \\
\text { (1) }\end{array}$ & $\begin{array}{c}\text { Mean } \\
\text { (Proportions) } \\
\text { (2) }\end{array}$ & $\begin{array}{l}\mathrm{SD} \\
(3)\end{array}$ \\
\hline Basic capital (in 1,000 rubles) & 3,527 & $1,654.216$ & $4,287.309$ \\
\hline Number of partners in founding team ... & 3,527 & 2.977 & 3.132 \\
\hline Number of shares ....................... & 3,527 & $5,456.181$ & $14,384.540$ \\
\hline Share price (in rubles) $\ldots \ldots \ldots \ldots \ldots \ldots \ldots$ & 3,524 & 776.751 & $1,473.751$ \\
\hline \multicolumn{4}{|l|}{ Organizational form: } \\
\hline Joint stock (aktsionernoe obshchestvo) & 2,285 & .648 & \\
\hline $\begin{array}{l}\text { Share partnership (tovarishchestvo na } \\
\text { paiakh) .......................... }\end{array}$ & $\begin{array}{r}1,238 \\
4\end{array}$ & .351 & \\
\hline \multicolumn{4}{|l|}{ Location of corporation: } \\
\hline Entire empire .... & 168 & .048 & \\
\hline 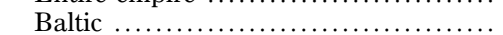 & 166 & .047 & \\
\hline 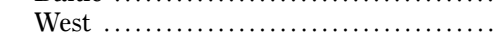 & 81 & .023 & \\
\hline South & 743 & .211 & \\
\hline Center & 802 & .227 & \\
\hline Volga-Ural & 214 & .061 & \\
\hline North ....... & 584 & .166 & \\
\hline Poland ....... & 350 & .099 & \\
\hline Caucasus & 236 & .067 & \\
\hline Central Asia & 60 & .017 & \\
\hline Siberia $\ldots \ldots \ldots \ldots \ldots$ & 87 & .025 & \\
\hline Finland $\ldots \ldots \ldots \ldots \ldots \ldots \ldots \ldots \ldots \ldots \ldots \ldots \ldots \ldots$ & 3 & .001 & \\
\hline Foreign countries & 22 & .006 & \\
\hline In Russian empire but exact location & & & \\
\hline unknown ........ & 11 & .003 & \\
\hline \multicolumn{4}{|l|}{ Industry sector of corporation: } \\
\hline Beets ........ & 226 & .064 & \\
\hline Malt ............. & 83 & .024 & \\
\hline Textile ... & 68 & .019 & \\
\hline Chemical & 118 & .034 & \\
\hline 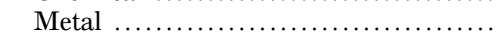 & 84 & .024 & \\
\hline Railway $\ldots \ldots \ldots \ldots \ldots \ldots \ldots \ldots \ldots$ & 38 & .011 & \\
\hline River & 77 & .022 & \\
\hline 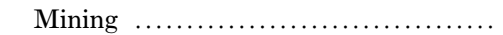 & 234 & .066 & \\
\hline Construction ....................... & 74 & .021 & \\
\hline Wholesale $\ldots \ldots \ldots \ldots \ldots \ldots \ldots \ldots \ldots \ldots \ldots$ & 207 & .059 & \\
\hline Finance $\ldots \ldots \ldots \ldots \ldots$ & 350 & .099 & \\
\hline Public administration .................. & 6 & .002 & \\
\hline Other manufacturing $\ldots \ldots \ldots \ldots \ldots \ldots \ldots$ & 1,739 & .493 & \\
\hline Other transport $\ldots \ldots \ldots \ldots \ldots \ldots \ldots \ldots \ldots$ & 217 & .062 & \\
\hline Unclassifiable .. & 6 & .002 & \\
\hline
\end{tabular}

NotE.-The source for all data is the RUSCORP database (Owen 1992). The table reports descriptive statistics for all corporations that were chartered in 1869-1913 and that are included in the analysis. Capital amounts are standardized and deflated to 1913 rubles. Share price is also reported based on the standard ruble of account. For the first four continuous variables (basic capital, number of partners, number of shares, and share price), col. 1 reports the number of corporations for which these data are available. For all other variables, col. 1 reports the number of corporations in each category, given that such data are available. For all categorical variables, col. 2 reports the proportion of corporations in each category. 
participate in successive foundings of companies over time. The noteworthy difference here is that, on average, serial founders were involved in corporate foundings with significantly larger amounts of basic capital than one-time founders, perhaps as an effect of learning-by-doing (col. 7). ${ }^{10}$

Table 2 details the founding activities of serial entrepreneurs in late imperial Russia. The mobilization of capital was not the only part, but certainly one of the most critical parts, of their activity (McKay 1970; Guroff and Carstensen 1983; Owen 2005). The information that potential founding partners and investors had access to beyond their local contact networks was often too diffuse to assess the prospects of new ventures (Stuart et al. 1999). We reason that a founding team's past success in mobilizing capital for a new enterprise contributes to a reputation of successful entrepreneurship that present investors may interpret as an indicator of the founders' performance potential. Investors may expect that past success leads to future success. ${ }^{11}$ Put differently, the amount of capital founders mobilized for a new enterprise may also be interpreted as the revealed preference of investors to promote that company. The founding of the Moscow-Tashkent Silk Company by such eminent Muscovite merchants as Fedor Chizhov and Timofei Morozov illustrates the importance of reputation, but it also demonstrates how looming business failure could undermine it. While faith in past achievements encouraged the founding associates to promote this silk cultivation enterprise, the government's insistence on publishing its accounts "aroused the investors' fears that the apparent lack of success in that risky undertaking might damage their reputations and weaken public confidence in their other enterprises" (Rieber 1982, p. 209).

We consider the reputation effect of previous success on future capital mobilization for each partner in the founding team. ${ }^{12}$ In particular, we

\footnotetext{
${ }^{10}$ The difference is slightly smaller when we compare the capital of one-time founders to serial founders in their first venture (mean capital $=2,074.158 ; \mathrm{SE}=158.9146 ; t$ ratio $=-2.6942$ ).

${ }^{11}$ We presume that information on mobilized capital was public. Tsarist corporate law required founders "not only to record all stock purchases in a special sealed book (shnurovaia kniga ) . . . , but also to account for the money thus collected in another book and to leave both books open for public inspection on the premises of the local municipal government until the subscription of shares has been completed" (Owen 1991a, p. 28). Referring to the case of Belgian entrepreneurs operating in Russia, McKay (1970, pp. 83-85) argues that signals of success travelled fast in close-knit groups of investors.

${ }^{12}$ Measuring reputation is meaningful only for persons with at least two observations over time. We find too many changes in membership composition over time for teams (rather than individual founders) to be an appropriate unit of analysis: only $15.7 \%$ of serial founders continue collaborations with previous partners (table 2); merely $4.3 \%$ of founding teams reoccur with the same partners.
} 
measure success in a previous founding $(t-1)$ as the amount of capital raised relative to the median amount of basic capital assembled by other founding teams in the same industry, location, and decade. ${ }^{13}$ For example, the 4,423,000 rubles (1913 ruble value) that one Benedikt Givartovskii and his 14 partners mobilized in 1875 to establish the First Moscow Streetcar Company exceeded the median basic capital of other new corporations in the transportation sector in the Moscow center region in the 1870 s, and therefore we define this founding as successful. ${ }^{14}$ An important concern here is to what extent the potential to attract contributions to basic capital may also tell us anything about corporate economic performance because basic capital itself is not a direct measure of a firm's performance. Our robustness analysis in the appendix demonstrates that success in the mobilization of basic capital is indeed systematically related to performance: the survival rate for companies we coded as successful is significantly higher than the rate for companies that raised less capital (fig. A1).

The results in table 2 further show that about $36 \%$ of the 1,832 observed founding activities of all serial entrepreneurs in our sample enjoyed such success in past foundings and that in $20 \%$ of the cases, the founding team included at least one previously successful partner (col. 5). The remaining variables in table 2 consider continued collaborations, which may have signaled the benefits of trust-filled relationships, and the frequency, timing, and diversity of foundings by individual entrepreneurs.

\section{Network Data}

To assess the salience of variation in network patterns for entrepreneurship, we coded affiliation networks of cofounding ties among individual

${ }^{13}$ To ensure sufficient observations for calculating median capital, we combine the more fine-grained industry classifications in table 1 into six larger categories: mining $(n=234)$, construction $(n=74)$, manufacturing $(n=2,318)$, transportation $(n=332)$, wholesale $(n=207)$, and finance $(n=350)$. The only small category remaining is public administration $(n=6)$. We exclude the six unclassifiable enterprises in table 1 .

${ }^{14}$ We code previous success as a binary indicator to distinguish founders with a good reputation from others since unit changes in a continuous capital variable do not make this distinction. A continuous measure of capital also misses the variation in the distribution of basic capital across industries and within industries over time. Figure A2 in the appendix illustrates this variation in capital for the transportation industry, including railways and river shipments. Clearly, the capital of other corporations within the same industry and period should be the comparison set for selecting the appropriate cut-off value. A higher cut-off than the median capital amount (e.g., the upper $80 \%$ or $90 \%$ in the distribution) is unlikely to change our findings. Our regression results already show that reputation is positively related to capital mobilization when we use such a relatively low benchmark as the median capital. Our findings would be even stronger if we would select a less conservative cut-off than the median. 
TABLE 2

Founder CharaCteristics, I869-I9I3

\begin{tabular}{|c|c|c|c|c|c|c|c|}
\hline & \multicolumn{3}{|c|}{ One-Time Founders $(N=8,709)$} & \multicolumn{3}{|c|}{ SERIAL Founders $(N=768)$} & \multirow[b]{2}{*}{$\begin{array}{c}\text { Significant } \\
\text { Difference } \\
\quad(7)\end{array}$} \\
\hline & $\begin{array}{c}\text { Observations } \\
\text { (1) }\end{array}$ & $\begin{array}{c}\text { Mean } \\
\text { (Proportions) } \\
(2)\end{array}$ & $\begin{array}{l}\text { SD } \\
(3)\end{array}$ & $\begin{array}{c}\text { Observations } \\
\text { (4) }\end{array}$ & $\begin{array}{c}\text { Mean } \\
\text { (Proportions) } \\
(5)\end{array}$ & $\begin{array}{l}\mathrm{SD} \\
(6)\end{array}$ & \\
\hline \multicolumn{8}{|l|}{ Founding activity: } \\
\hline Basic capital (in 1,000 rubles) & 8,709 & $1,614.490$ & $4,508.248$ & 1,832 & $2,216.674$ & $4,771.562$ & $-5.143 * * *$ \\
\hline Ego's previous success $\ldots \ldots \ldots \ldots \ldots \ldots \ldots$ & & & & 1,832 & .356 & & \\
\hline Partners' previous success $\ldots \ldots \ldots \ldots \ldots \ldots$ & & & & 1,832 & .200 & & \\
\hline Continued partnerships $\ldots \ldots \ldots \ldots \ldots \ldots \ldots$ & & & & 1,077 & .157 & & \\
\hline Number of corporate foundings $\ldots \ldots \ldots \ldots$ & & & & 1,832 & 2.843 & 1.593 & \\
\hline Years between subsequent foundings ........ & & & & 1,077 & 4.751 & 6.651 & \\
\hline Number of different regions $\ldots \ldots \ldots \ldots \ldots \ldots$ & & & & 1,301 & .394 & .810 & \\
\hline As proportion of all foundings by founder ... & & & & 1,301 & .139 & .233 & \\
\hline Number of different industries $\ldots \ldots \ldots \ldots \ldots$ & & & & 1,093 & 677 & .940 & \\
\hline As proportion of all foundings by founder ... & & & & 1,093 & .244 & .261 & \\
\hline \multicolumn{8}{|l|}{ Founders' ethnic background: } \\
\hline 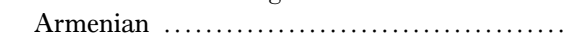 & 159 & .018 & & 29 & .038 & & $13.807 * * *$ \\
\hline 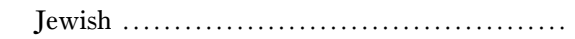 & 990 & .114 & & 99 & .129 & & 1.610 \\
\hline 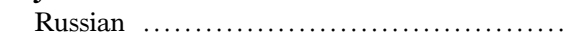 & 4,194 & .482 & & 410 & .534 & & $7.723 * * *$ \\
\hline 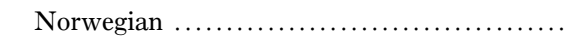 & 723 & .083 & & 51 & .066 & & 2.597 \\
\hline French & 83 & .010 & & 4 & .005 & & 1.449 \\
\hline German & 1,448 & .166 & & 107 & .139 & & $3.735^{*}$ \\
\hline
\end{tabular}




\begin{tabular}{|c|c|c|c|c|c|}
\hline Greek & 95 & .011 & 10 & .013 & .288 \\
\hline Tatar & 125 & .014 & 9 & .012 & .351 \\
\hline Other & 892 & .102 & 49 & .064 & $11.771 * * *$ \\
\hline Foreign citizenship $\ldots \ldots \ldots \ldots \ldots \ldots \ldots \ldots \ldots$ & 324 & .037 & 34 & .044 & .970 \\
\hline \multicolumn{6}{|l|}{ Founders' status: } \\
\hline Nobility $\ldots \ldots \ldots \ldots \ldots$ & 470 & .054 & 66 & .086 & $13.519 * * *$ \\
\hline Government official ........................ & 959 & .110 & 115 & .150 & $11.027 * * *$ \\
\hline 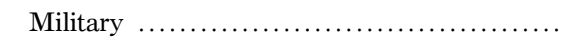 & 403 & .046 & 18 & .023 & $8.670 * * *$ \\
\hline Educational/professional estates .............. & 981 & .113 & 89 & .116 & .074 \\
\hline Commercial, industrial, financial/urban estates & 4,319 & .496 & 381 & .496 & .0001 \\
\hline Landed estates $\ldots \ldots \ldots \ldots \ldots \ldots \ldots \ldots \ldots$ & 1,230 & .141 & 68 & .089 & $16.577 * * *$ \\
\hline Religious officials $\ldots \ldots \ldots \ldots \ldots \ldots \ldots \ldots$ & 1 & .001 & 0 & .000 & .088 \\
\hline Organizations as founders $\ldots \ldots \ldots \ldots \ldots \ldots$ & 346 & .040 & 31 & .040 & .008 \\
\hline
\end{tabular}

Note.-The source for all data is the RUSCORP database (Owen 1992). Capital values are standardized and deflated to 1913 rubles. Success is lagged by one previous founding event and equals one if a founder mobilized basic capital for a previous corporation that was equal to or exceeded the median capital for all other corporations founded in the same industry, region, and decade. Measurement of partner's success follows the same rationale, but it is applied to a founder's current partners in a founding team. Repeated partnership equals one if one or more of a founder's current partners were also his partners in a previous founding team. Observations are person-years; the number of unique founders are reported in the column headers. Significant differences compare means $\left(t\right.$-statistic) and proportions $\left(\chi^{2}[d f=1]\right)$ between one-time and serial founders.

$* P<.10$.

** $P<.05$.

*** $P<.01$ 
founders and the companies in whose founding teams they participated. For our entire period of interest (1869-1913), we have cumulative network data on the affiliations among 11,545 founders and 4,172 companies. ${ }^{15}$ Since we are interested in the extent and persistence of structural cohesion versus fragmentation over time, we split these data into period-specific networks. Ideally, we will want a division into periods that does not artificially create fragmentation by cutting off observed ties. We also need a sufficient number of discrete periods to reveal potential changes in the network patterns. Our solution is a periodization based on the observed duration between subsequent foundings (see table 2). On average, foundings were about four to five years apart. We opted for a conservative estimate of network fragmentation and split the time-axis into five eightyear periods. Eight years is about twice the average duration between foundings and comfortably includes the majority of founding sequences of individual entrepreneurs within each period (the last period, 1909-13, contains only five years but a much larger number of founders than the other periods). Because we do not know when partnership ties ended for all corporations in our data, this periodization is likely to be biased toward cohesion among founders and therefore yields conservative estimates of fragmentation.

For each period, we first constructed a binary founder-by-company matrix with founders arrayed in rows and companies in columns. Each cell reports if an entrepreneur was a member of the company's founding team or not. We then transformed the eight matrices into a symmetric founder-by-founder matrix and a corresponding symmetric company-bycompany matrix. Within each founder-by-founder network, pairs of founders are linked to the extent that they were partners in the founding of the same companies. Entries are equal to zero absent such cofounding ties. The corresponding company-by-company networks record the number of founders that each pair of companies has in common and documents the extent of interlock between founding teams.

Figure 2 maps the cumulative founder-by-founder network over the entire 1869-1913 period. The nodes represent individual entrepreneurs, linked by their joint membership in the same founding teams. ${ }^{16}$ We use a graphing algorithm that draws the network in such a way that the distance between founders is proportional to the shortest path linking

\footnotetext{
${ }^{15}$ The numbers in tables 1 and 2 are smaller because information is missing for some variables.

${ }^{16}$ Normalizing tie strength is not an issue. First, we are interested in the shape of network patterns and not in the strength of dyadic ties. Second, dyadic tie strength varied little: the maximum tie value for the entire $1869-1913$ period equals 4 ; only 178 out of all 38,456 ties among the 11,545 founders have a value greater than one.
} 


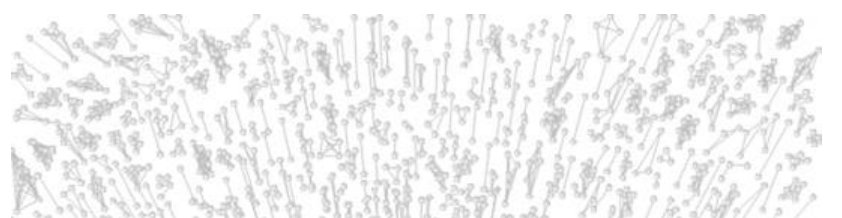

窟余骂

部

쿵

屯े :

政

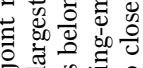

-

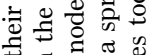

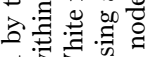

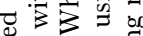

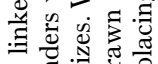

8.

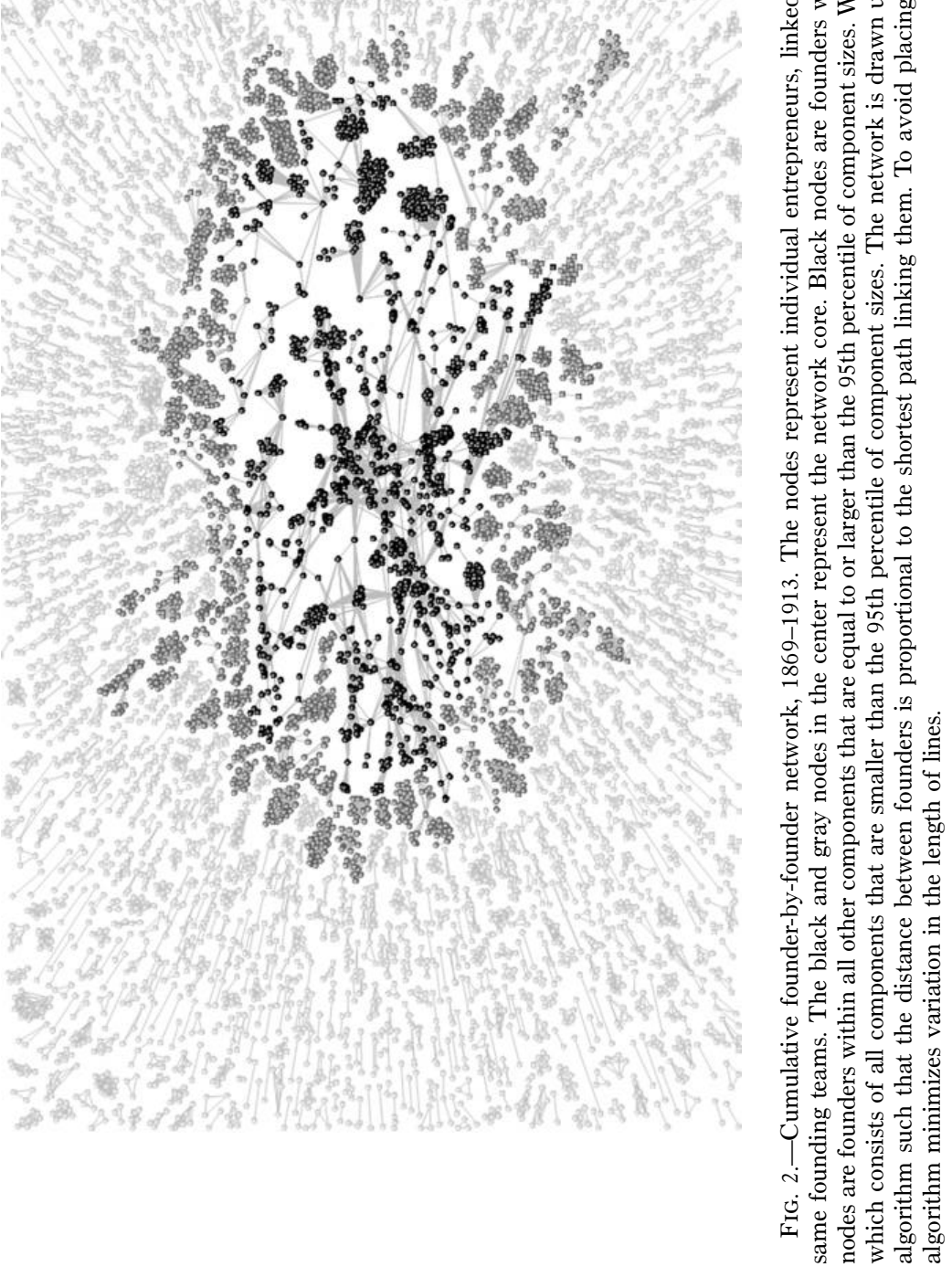


them. To avoid placing nodes too close to each other, the algorithm minimizes variation in the length of lines. Immediately visible is the partition of the network into a well-connected core (gray and black nodes) around a cohesive main component (black nodes only) and a surrounding fragmented network periphery (white nodes) consisting of a multitude of small components that are disconnected from each other. ${ }^{17}$ Here we should remind the reader that positions in the core and periphery of the corporate partnership network should not be interpreted as being congruent with locations in the economic and political geography of the Russian empire, such as the Muscovite core versus regional peripheries (Rieber 1982). If we define the geographic core to include Moscow and its surrounding provinces, then cross classification reveals no significant overlap between geographic location and network position: in our panel data, $60.5 \%$ of observations located in the geographic periphery belong to the network core. Similarly, $57.6 \%$ of observations in the Moscow core occupy positions in the network core. Hence, differences between geographic locations are not reflected in corresponding differences between network positions $\left(\chi^{2}[d f\right.$ $=1]=1.1377 ; P=.286) .{ }^{18}$ The finding does not imply that geography and regional identities played no role in the economic relationships we examine here. But it suggests that a substantial number of entrepreneurs did not rely solely on their regional attachments when they selected partners for their corporate founding teams.

Likewise, we do not simply confound the periphery with one-time founders and the core with serial entrepreneurs: $31.5 \%$ of the observed founding activities of one-time founders in our sample are embedded in the network core, and $39.6 \%$ of the founding activities of serial entrepreneurs occur in the periphery. Nor are core positions and success in

\footnotetext{
${ }^{17}$ Because a large number of mutually reachable founders characterizes a cohesive network core (Moody and White 2003), we define the core as consisting of all components that are equal to or larger than the 95th percentile of component sizes in each period (see table 4). All other components and isolates belong to the periphery.

${ }^{18}$ Results refer to the serial founders included in our regressions $(n=1,832)$. The geographic indicator equals one if a venture is located in one of the following provinces and zero otherwise: Vladimir, Voronezh, Kaluga, Kostroma, Kursk, Moscow, Orel, Penza, Riazan, Tambov, Tver, Tula, Iaroslavl. The results are similar if we include one-time founders $\left(\chi^{2}[d f=1]=.0030 ; P=.956\right)$ or include Petersburg, Odessa and their surrounding provinces in the geographic core $\left(\chi^{2}[d f=1]=.3731 ; P=.541\right)$. Consequently, interpretations of differences in the economic geography between the Russian heartland and peripheral regions are not well suited to explain the split within the corporate network into a cohesive core and a fragmented periphery. Such interpretations refer to differential stages of industrial development between the geographic center and the periphery, comparative advantages gained through regional specialization, differences in the stratification of ethnicities between the Russian heartland and the peripheral provinces, and differences in the timing of geopolitical incorporation of peripheral regions into the Russian imperial polity (Weeks 1996; Bassin 1999; Kappeler 2001; Brower 2003).
} 
mobilizing capital perfectly overlapping: $34.3 \%$ of the founding activities of founders we classified as not successful are embedded in the core, and $34.8 \%$ of those we coded as successful occur in the periphery.

\section{REPUTATION AND CAPITAL MOBILIZATION}

We first consider to what extent a reputation of past success contributed to the mobilization of basic capital, a central activity of merchant entrepreneurs (McKay 1970; Guroff and Carstensen 1983). As noted earlier, we suggest that founding team partners and investors may interpret a founder's past success in raising capital for his previous enterprises as an indicator of his performance potential. That is, current partners and investors consider the revealed preference of past sponsors as a cue to decide whether they should promote the new enterprise by the same founder or not. Reputation in this sense is used to cope with the uncertainty of future performance. Continued success in raising sufficient funds for various enterprises expresses a reputation in another sense as well: to the extent that other promoters are repeatedly willing to offer their support, they signal that such founders are credible and trustworthy business partners who do not deceive their investors or founding partners. Network closure that embeds founders and investors through a high density of ties supports this credibility because it facilitates both the enforcement of collective norms against fraud and the flow of information about credible partners among potential promoters. An illustration of such cohesion are the Old Believer merchants who "trusted each other . . . because a network of personal relationships . . . provided crucial financial and commercial support, including interest-free loans, so that ostracism on account of dishonesty toward a coreligionist meant economic ruin" (Owen 1983, p. 60). Crisp (1976, p. 114) similarly notes of the developing credit market that "on the local but to an overwhelming extent also on the regional and national level face to face relations or recommendations of persons of proven probity were the basis of credit." Relational closure thus increases the costs associated with losing one's reputation (Coleman 1990; Burt 2005; Greif 2006). We argue that such a reputation mechanism operated as a private-order safeguard against the often widespread embezzlement of initial share capital when reliable public institutions to protect stockholders' rights were lacking. ${ }^{19}$

\footnotetext{
${ }^{19}$ Owen (1991a, p. 29) notes that "corporate founders had learned a clever way to benefit at the expense of the stockholders: to bestow upon themselves, free of charge, a large portion of the corporation's initial stock as compensation for their entrepreneurial efforts. Having invested nothing of their own, they could dispose of the company quickly, taking a profit on the sale of their shares to the public."
} 
In table 3, we consider this reputation mechanism. We present least squares estimates of the influence of partners' prior success and repeated partnerships on the mobilization of basic capital for new enterprises founded by serial entrepreneurs. Again, we focus on serial founders because only they could have built a reputation for success over time and engaged in repeated partnerships with other founders. ${ }^{20}$ The dependent variable in all specifications is the variation in logged basic capital, standardized and deflated to 1913 rubles. ${ }^{21}$ All regressions include fixed effects for years in which corporations were founded to control for year-specific impacts on the amount of capital raised. We use Hubert and White robust variance estimates to adjust for nonindependence among observations within the same founding team. ${ }^{22}$

Recall that we measure success in a previous founding $(t-1)$ as the value of capital raised relative to the median basic capital mobilized by other founding teams in the same industry, location, and decade. In columns 1 and 2 in table 3, we find that the reputation effect of previous success is indeed far from trivial. Having one or more successful partners on one's founding team significantly increased the value of basic capital between $14 \%$ and $17 \%$ as compared to founding teams that lacked partners with a history of success (we address the potential endogeneity in the relationship between capital mobilization and partner choice in the appendix. ${ }^{23}$ Our robustness checks demonstrate that the choice of founding partners was not primarily dictated by requirements to raise sufficient funds for an enterprise).

The result lends systematic support to our reputation argument. Still, variation in mobilizing capital may have been a result of unobserved individual heterogeneity across founders. Some may have been particularly skillful in promoting their enterprises compared to others who lacked

\footnotetext{
${ }^{20}$ Robustness checks demonstrate that the estimates for our main variables (reputation and network position) in tables 3 and 5 retain their direction and magnitude if we include both one-time and serial founders (these results are available from the authors).

${ }^{21}$ We estimate capital on a logarithmic scale because the distribution of basic capital is highly skewed.

${ }^{22}$ Estimating period-specific autocorrelation models to control for network dependencies also confirms the least squares results.

${ }^{23}$ Strictly speaking, our regressions are based on the population of serial entrepreneurs and not on a random sample of that population. Whenever we refer to the statistical significance of estimated coefficients, we have in mind a general statistical model where the reputation of founders predicts their potential to mobilize capital. What we observe in the Russian case is one realization of the underlying stochastic process that relates reputation and capital mobilization. The null hypothesis is that reputation is unrelated to capital mobilization. What makes this interpretation probabilistic is not that our inferences are based on a random sample but that some random component ("chance") may reveal that variation in reputation is unrelated to the amount of capital raised.
} 
TABLE 3

Least Squares Estimates of Basic Capital Raised by Founding Teams WITH SERIAL FoundERS, I869-I9I3

\begin{tabular}{|c|c|c|c|c|}
\hline & \multicolumn{2}{|c|}{ OLS } & \multicolumn{2}{|c|}{$\begin{array}{l}\text { FOUNDER FIXED } \\
\text { EFFECTS }\end{array}$} \\
\hline & (1) & (2) & (3) & (4) \\
\hline Partner's previous success .. & $\begin{array}{l}.172 * * * \\
(.051)\end{array}$ & $\begin{array}{l}.144 * * * \\
(.055)\end{array}$ & $\begin{array}{l}.162 * * * \\
(.047)\end{array}$ & $\begin{array}{l}.174 * * \\
(.078)\end{array}$ \\
\hline Continued partnership $\ldots . .$. & & $\begin{array}{l}.154 \\
(.098)\end{array}$ & & $\begin{array}{l}.277 * * * \\
(.107)\end{array}$ \\
\hline $\begin{array}{l}\text { Experience (number of past } \\
\text { foundings) } \ldots \ldots \ldots \ldots \ldots \ldots\end{array}$ & & & $\begin{array}{l}-.008 \\
(.025)\end{array}$ & $\begin{array}{r}-.076^{*} \\
(.040)\end{array}$ \\
\hline Founder fixed effects $\ldots . . .$. & No & No & Yes & Yes \\
\hline Founder controls $\ldots \ldots \ldots \ldots$ & Yes & Yes & No & No \\
\hline Founding team controls ..... & Yes & Yes & Yes & Yes \\
\hline Year fixed effects $\ldots \ldots \ldots \ldots$ & Yes & Yes & Yes & Yes \\
\hline $\begin{array}{l}\text { Number of corporations } \\
\text { founded } \ldots \ldots \ldots \ldots \ldots . .\end{array}$ & 1,265 & 827 & 1,265 & 827 \\
\hline Number of serial founders .. & 773 & 764 & 773 & 764 \\
\hline Number of observations .... & 1,832 & 1,077 & 1,832 & 1,077 \\
\hline $\begin{array}{l}R^{2} \text { (within founder cases for } \\
\text { models } 3 \text { and } 4 \text { ) } \ldots \ldots \ldots \ldots . . . .\end{array}$ & .490 & .524 & .435 & .577 \\
\hline
\end{tabular}

NoTE.-The dependent variable is the logged basic capital of newly incorporated companies. SEs, adjusted for clustering within founding teams, are reported in parentheses. Capital values are standardized and deflated to 1913 rubles. Partner's success is lagged by one previous founding event and equals one if one or more partners in a founder's current partnership generated basic capital for a previous corporation that was equal to or exceeded the median capital for all other corporations founded in the same industry, region, and decade. Continued partnership equals one if one or more of ego's current partners were also ego's partners in a previous founding team. Founder controls include nationality/ethnic background and social status of founders. Founding team controls include the number of founders involved, number of shares issued, organizational form (joint-stock $=1$, otherwise $=0$ ), location within the Russian empire, and industry sector of the corporation. All regressions include fixed effects for years in which corporations were founded. The number of observations in models 2 and 4 decreases because continued partnerships can only be meaningfully measured from the second founding onward. Consequently, all instances of founding debuts are excluded in models 2 and 4 .

$$
\begin{aligned}
& * P<.10 . \\
& * * P<.05 . \\
& * * * P<.01 .
\end{aligned}
$$

such qualities. One way to control for individual-level skill differences is to exploit the panel nature of our data by using fixed effects estimates. ${ }^{24}$

${ }^{24}$ We find that within-founder variation is sufficient to employ fixed effects specifications. First, we include only serial founders in our regressions because measuring reputation requires at least two observations per founder. Second, in model 3 in table 3,99\% of all observations represent at least two events per founder. Merely 10 out of all 1,832 observations represent singular occurrences. We observe these 10 serial founders only once 
However, skill and related sources of heterogeneity across individual founders may vary over time. We therefore use the number of previous foundings that an entrepreneur was involved in as an additional time-varying indicator of his founding experience beyond the time-invariant qualities captured by our fixed effects estimates. The underlying assumption is that the number of foundings reflects an entrepreneur's learning-by-doing experience. ${ }^{25}$ The results in columns 3 and 4 in table 3 demonstrate that the positive influence of a partner's reputation on a company's capitalization holds even if we take such individual-level heterogeneity into account: joining with previously successful partners still increases the value of basic capital significantly by at least $16 \%$.

Besides individual differences, a self-selection mechanism may generate our results, where entrepreneurs will weigh the opportunity costs of founding a new venture before committing themselves to it. Previously successful founders may only engage in new enterprises that promise to be successful as well, and this preference may generate the positive relationship between past success and present capital mobilization we observe. We find no supporting evidence for this self-selection: a full third (33.24\%) of previously successful founders engage in a nonsuccessful founding, whereas previously unsuccessful founders are equally likely to transition to successful (48.88\%) and nonsuccessful $(51.12 \%)$ foundings $\left(\chi^{2}[d f=1]\right.$ $=36.21 ; P<.0001)$. In addition, founding in this context is not an individual decision, which is precisely the reason why we focus on having reputable partners on a team: $89 \%$ of all founder observations had at least one partner; table 1 reports a mean of three partners per venture; and our observed founding teams included up to 70 partners.

An additional strategy for merchant entrepreneurs to pursue beyond the reliance on successful founding careers is to continue a past partnership, possibly because it proved to be an exceptionally productive one. Especially in settings where public institutions are weak, continued partnerships provide opportunities for forging trust-filled relationships as substitutes for legal safeguards (Fafchamps 2004). To compare the role of reputation with the potential advantages of continued partnerships, we use a binary measure: it equals one if a founder keeps collaborating with

\footnotetext{
because their other founding events occur before 1869 and are left-censored. Third, model 4 adds continued partnerships as a covariate, which excludes each individual's initial founding because it cannot continue any previous partnership. Consequently, 588 out of the 1,077 observations in model 4 represent singular occurrences. But even this constraint still leaves us with within-founder variation for about half of the 1,077 observations included in the regression.

${ }^{25}$ We also estimated linear and quadratic trends for the number of years since the first founding as controls for individual-level heterogeneity. Using these alternative indicators of time-varying skills confirms the direction, magnitude, and significance of our main effects.
} 
partners from previous enterprises and equals zero otherwise. The results in table 3 reveal a positive influence of such repeated partnerships; this is roughly similar in magnitude to the effect of a positive reputation, with the exception of the fixed effects estimates. Still, the estimates for our main variable of interest, a reputation of past success, remain robust. In sum, reputation, understood as a signal of a successful entrepreneurial career of a credible founder, indeed had a significant positive influence on the mobilization of basic capital across varying specifications. ${ }^{26}$

\section{THE SOCIAL STRUCTURE OF CORPORATE FOUNDING}

\section{Network Fragmentation}

One starting point for our argument was the observation that emergent societies are typically characterized by fragmented social structures. They therefore often lack the globally cohesive networks necessary for effective enforcement through reputation-based private-order institutions. Our next task is to document the extent of fragmentation within the cofounding networks among Russian entrepreneurs. The graph in figure 2 obtains its structure primarily from the absence of relationships between components. This pattern reveals that fragmentation existed, particularly among founders located in the network periphery. The results in table 4 support this visual observation with quantitative evidence for the persistence of structural fragmentation in each period. Column 1 in table 4 reports the number of founders in each period-specific cofounding network. Not all firms in our sample were large joint-stocks, and it was possible for a single entrepreneur to initiate a founding. Yet, the low counts of isolated founders in column 2 indicate that it was uncommon to establish companies singlehanded instead of forming partnerships. This finding also demonstrates that any observed lack of overall cohesion does not stem simply from the presence of a large proportion of isolated founders. ${ }^{27}$

An intuitive measure of fragmentation is the proportion of founder pairs that are unable to reach each other through their network ties, either directly or through third parties. Networks become more fragmented as

${ }^{26}$ Using interactions between reputation and period indicators shows no evidence that the relationship between reputation and capital mobilization changed over time as a consequence of shifting government policies when a new tsar ascended to the throne in 1881 and after 1894. When added to the estimations in table 3 (and table 5), none of the period interactions yield significant effects, whereas all coefficients for the main reputation effect remain robust (these results are available from the authors).

${ }^{27}$ The share of isolated founders increases over time, from $1 \%$ to $15 \%$. But col. 3 in table 4 shows that this increase has little impact on the proportion of mutually unreachable pairs. The increase in isolates did not help to overcome fragmentation, but little evidence suggests that they were primarily responsible for the lack of cohesion. 


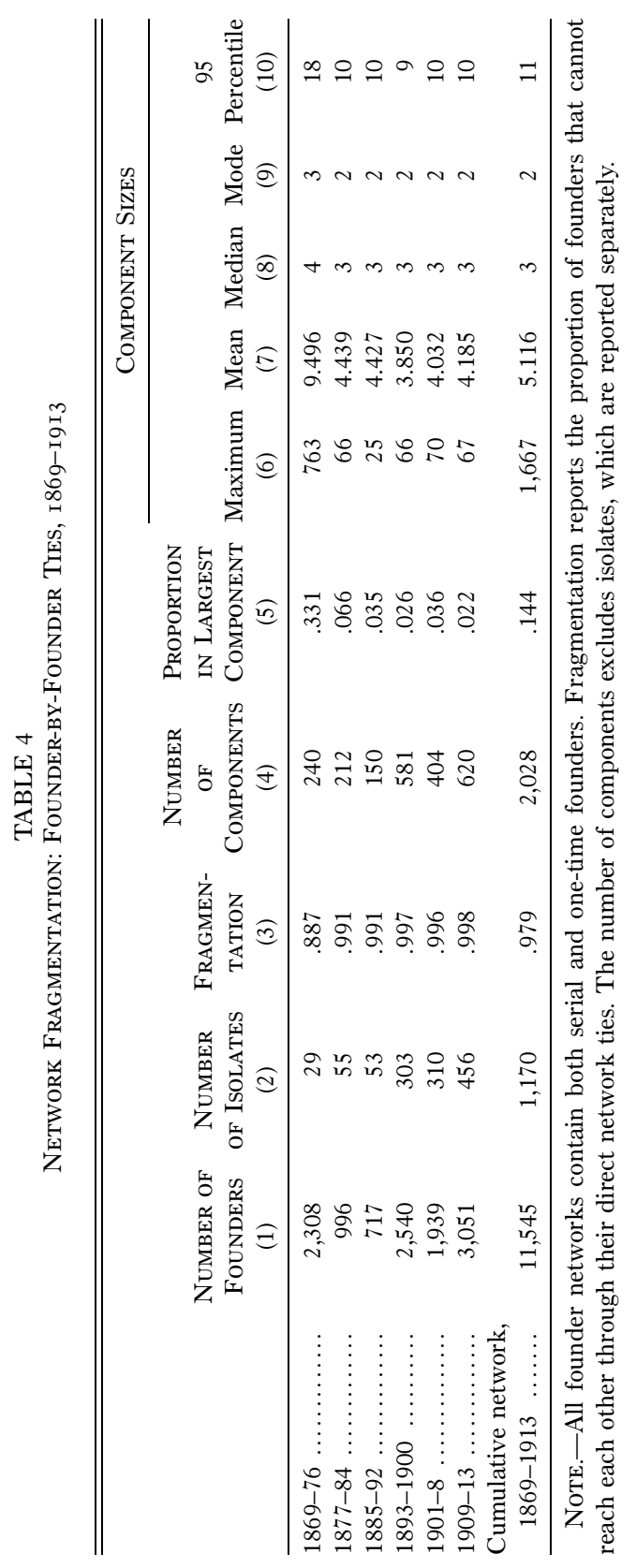


the proportion of mutually unreachable dyads reaches a value of one. Column 3 documents that fragmentation was indeed pervasive across all periods because few entrepreneurs were linked through their cofounding ties. The measure offers preliminary evidence but less detail about the underlying pattern of ties. Affiliation networks invariably generate a pattern of local clustering that reflects underlying group membership. Still, we may ask, for example, if bridges and brokers help to cluster the linked founders into a few large groups or if founders evenly distribute themselves across a large number of small groups.

A useful alternative measure of fragmentation that takes the topology of networks into account is the number and size of components. Substantively, components identify subgroups in a network such that each member of a component can reach every other member by at least one pathway, using one's direct contacts and their subsequent contacts (Moody and White 2003). The important point for our purpose is that components are mutually exclusive subgroups with no bridges between them. Consequently, a network that consists of a large number of distinct components exhibits structural fragmentation. Columns 4-10 in table 4 report the number and membership sizes of components in each period-specific network.

Three findings emerge. First, all cofounding networks break into a large number of small components relative to the total number of founders, indicating fragmentation. Many entrepreneurs in late imperial Russia were thus embedded in cofounding groups that included only a few members and rarely interlocked with each other (cols. 8 and 9). ${ }^{28}$

Second, in each period, we find that the size of the largest (main) component, and hence the proportion of founders embedded within it, is small relative to the overall network size (col. 5 in table 4). By definition, a large proportion of nodes in the main component of a network implies that the majority of founders is connected. Consequently, our result is yet another indicator of fragmentation because the larger proportion of founders is instead located in the hundreds of scattered smaller components shown in figure $2 .{ }^{29}$ This picture also contrasts with recent studies of similar collaboration networks such as coauthorship networks, the production of Broadway musicals, or biotechnology organizations that find up to 53\% (Moody 2004), 94\% (Uzzi and Spiro 2005), and even $98.6 \%$

\footnotetext{
${ }^{28}$ As there are also hundreds of companies in each period network, such splintering may not come as a surprise. But it takes only a few founders involved in more than one company to fill positions as cutpoints that connect such separate components.

${ }^{29}$ Robustness checks using network simulations to assess the significance of the low proportion of founders in the main component show that the observed proportions are substantially lower than those expected by chance (these results are available from the authors).
} 
(Powell et al. 2005) of nodes connected within the main component. For comparison, even in the most cohesive network we observe (in the first period, 1869-76), only 33\% of all founders are contained within the main component. The contrast and significance of fragmentation is even more pronounced once we consider the mere $2.2 \%$ to $6.6 \%$ of founders who are located in the main component in the other periods. ${ }^{30}$

Third, we find that overall integration between components did not increase and consequently that fragmentation persisted over time. Exempting the more cohesive first period (1869-76), the percentage of mutually unreachable founders remains consistently at $99 \%$. The percentage of founders in the main component similarly stays at the same low end between $2.2 \%$ and $6.6 \%$. Likewise, the variation in the descriptive statistics for component sizes across periods is small. If anything, fragmentation increased over time, considering the noteworthy change following the first period.

The last row in table 4 documents that these results are not mere artifacts of our chosen periodization, which may have arbitrarily cut off collaborative ties and induced fragmentation. The most conservative approach to address this concern is to neglect the decay of ties and founders altogether: the statistics for the entire 1869-1913 period network clearly show that $98 \%$ of all founders still cannot reach each other. Likewise, merely $14.4 \%$ of founders in the main component is still a substantially lower percentage compared to the 53\%-98.6\% found in previous studies of affiliation networks (Moody 2004; Powell et al. 2005; Uzzi and Spiro 2005).

\section{Capital Mobilization in the Core and the Periphery}

The next intuitive question is whether reputation was equally salient for mobilizing capital in the core and the periphery of the Russian partnership

\footnotetext{
${ }^{30}$ One reviewer wondered if the large main component in the first period (1869-76) shapes our findings. In all our regressions, we include dummy indicators for each year to control for potential period effects. Across all OLS specifications, only the year 1870 is significantly related to capital mobilization. We also reestimated all regressions without members of the first period network to assess potential cohort effects. We excluded founders who began their careers before 1869 but were still active in 1869-1876 and all founders who began their founding activity during the period $1869-76$. The results in table A4 in the appendix demonstrate that our inferences are not merely an outcome of selection on members of the first period cohort: the estimates for our main variables of interest remain consistent in their direction and significance with the results obtained from our full sample (tables 3 and 5), and they shift only marginally in their magnitude (the only exception is the loss in statistical significance of the network core coefficients). To the best of our knowledge, no particular historical circumstances existed during the first period that explain the size of the main component in the first period and its decline in later periods.
} 
network or not. Again, the important point here is that reputation requires a particular social structural foundation-namely, network closure-to work as a credible enforcement mechanism (Coleman 1990). By contrast, the greater diversity and connectivity through bridges and brokers in the core suggests that core positions offered better access to diverse sources of capital than the periphery. Our second task in this section is to provide direct evidence that capital mobilization varied systematically with the pattern of social relationships in which founders were embedded (Stuart et al. 1999). Ultimately, we seek to answer the question as to which social organizational foundations were better suited to support successful founding strategies in settings where network fragmentation combined with weak institutional support.

The results in column 1 in table 5 address the first question, to what extent reputation was equally salient for founders positioned in core and periphery. We use the same OLS set-up as in table 3, this time adding the effect of membership in the network core and its interaction with a founding partner's reputation of success. The evidence reveals that founders who were embedded in the core enjoyed a comparatively small additional benefit from also having partners with a good reputation on their founding teams: for them, successful entrepreneurship in the past increased the expected basic capital by $19 \%$. In the periphery, the effect of reputation was twice as large: there, having a partner who was known as a successful founder raised the basic capital by $39 \%$. The results do not imply that, in the core, reputation and a founder's network position were direct substitutes for each other. But they do imply that the role of reputation for capital mobilization was significantly less salient in the core compared to the network periphery. Again, to understand the differential influence of reputation, we suggest looking beyond individual behavior and positioning and focusing on the broader pattern of affiliations within which founders are embedded: the closed pattern of affiliations in the periphery supports monitoring and sanctioning based on reputation costs, and such network closure is significantly less prevalent in the core of the partnership network.

The main effect of core membership in table 5 indicates that, all else equal, core positions should have been more desirable than peripheral ones because they offered better opportunities for raising more capital. Compared to peripheral locations, founding teams in core positions did enjoy an $11 \%$ increase in expected basic capital. But if the more lucrative positions in the core are not accessible, local closure in the periphery, based on homophily in partner choice or other grounds, may become valuable. ${ }^{31}$ Locally at least, reputation is significantly more relevant for

\footnotetext{
${ }^{31}$ Low mobility rates from the network periphery to the core indicate such entry barriers.
} 
TABLE 5

Least Squares Estimates of Basic Capital Raised

by Founding Teams with Serial Founders, I869-igi3: Network Effects in CORE ANd Periphery

\begin{tabular}{|c|c|c|c|}
\hline & \multirow{2}{*}{$\frac{\text { CORE EFFECT }}{(1)}$} & \multicolumn{2}{|c|}{ CONSTRAint EFFECT } \\
\hline & & (2) & (3) \\
\hline Partner's previous success $\ldots \ldots \ldots \ldots$ & $\begin{array}{l}.391 * * \\
(.162)\end{array}$ & $\begin{array}{l}.384 * * \\
(.164)\end{array}$ & $\begin{array}{l}.151^{* * * *} \\
(.055)\end{array}$ \\
\hline Network core membership ......... & $\begin{array}{l}.114^{*} \\
(.066)\end{array}$ & $\begin{array}{l}.102 \\
(.066)\end{array}$ & \\
\hline $\begin{array}{l}\text { Partner's previous success } \times \\
\quad \text { network core membership } \ldots \ldots . .\end{array}$ & $\begin{array}{r}-.316^{*} \\
(.182)\end{array}$ & $\begin{aligned}-.298 \\
(.184)\end{aligned}$ & \\
\hline Founder's network constraint & & $\begin{array}{l}-.214 * * \\
(.094)\end{array}$ & $\begin{array}{l}-.231 * * \\
(.093)\end{array}$ \\
\hline Continued partnership..$\ldots \ldots \ldots \ldots$ & $\begin{array}{l}.137 \\
(.098)\end{array}$ & $\begin{array}{l}.136 \\
(.099)\end{array}$ & $\begin{array}{l}.152 \\
(.098)\end{array}$ \\
\hline Founder controls $\ldots \ldots \ldots \ldots \ldots \ldots$ & Yes & Yes & Yes \\
\hline Founding team controls $\ldots \ldots \ldots \ldots$ & Yes & Yes & Yes \\
\hline Year fixed effects .................... & Yes & Yes & Yes \\
\hline Number of corporations founded .. & 827 & 827 & 827 \\
\hline Number of serial founders $\ldots \ldots \ldots$ & 764 & 764 & 764 \\
\hline Number of observations ............. & 1,077 & 1,077 & 1,077 \\
\hline$R^{2} \ldots \ldots \ldots \ldots \ldots \ldots \ldots \ldots \ldots \ldots \ldots \ldots \ldots \ldots \ldots \ldots$ & .527 & .529 & .527 \\
\hline
\end{tabular}

NoTE.-The dependent variable is the logged basic capital of newly incorporated companies. SEs, adjusted for clustering within founding teams, are reported in parentheses. Capital values are standardized and deflated to 1913 rubles. Network core membership is a binary indicator. The network core consists of all components that are equal to or larger than the 95th percentile of component sizes. All other components and isolates are defined as the network periphery. Founder's network constraint measures the extent of closure among each founder's direct network contacts, using Burt's (1992) measure of constraint, scaled to range between zero and one. Both core membership and network constraint are measured as time-varying covariates. All regressions include fixed effects for years in which corporations were founded. For all other measurements, refer to table 3 .

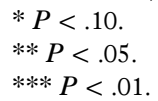

raising capital within the small yet tightly knit networks we find in the periphery. There, news about fraudulent behavior travels instantaneously, and the capacity for sanctioning is much greater than in the wide-reaching core component (Coleman 1990).

When we consider the social organizational basis of entrepreneurship, a simple indicator that distinguishes occupants of core and peripheral positions is arguably not the most fine-grained representation of differ-

Over all periods, we find considerable movement from the core to the periphery, but on average only $25 \%$ of all founders in the periphery moved into the network core in a subsequent period. 
ences in their underlying patterns of affiliations. To get at more nuanced micro-level network correlates of capital mobilization, we measure network constraint (Burt 1992). In our case, founders are constrained to the extent that their partners are also partnering with each other-if all of one's partner do so, local closure results and channels for reaching information and resources become redundant yet enforcement is eased. This scenario mostly reflects the social structure among entrepreneurs in the periphery. In contrast, founders are less constrained when they join with partners who are otherwise not connected with each other. This condition describes the potential for network reach through bridging across diverse groups that we observe primarily in the core. The measure thus has the advantage of capturing both local closure and opportunity structures for reach through brokerage in a single statistic.

Table 6 presents means comparisons for founders' constraints in the core and the periphery for each period network (cols. 3-5) ${ }^{32}$ In all periods, the extent of network reach and brokerage opportunities was consistently greater in the core than in the periphery (recall that higher constraint indicates closure and less brokerage). ${ }^{33}$ Columns $6-8$ in table 6 indicate that founders in the core were able to translate these social-relational opportunities into economic advantages. During most years, core entrepreneurs raised significantly larger amounts of basic capital than their peers in the periphery (using our reputation variable instead of mean capital likewise shows a significantly higher proportion of successful founders in the core than in the periphery).

Returning to table 5, the regressions in columns 2 and 3 provide further evidence for the benefits of network reach in a multivariate specification. Column 2 adds founder's constraint to the interaction of reputation and core membership. Increasing constraint in one's partnership network

\footnotetext{
${ }^{32}$ We also considered ethnic brokerage, using Gould and Fernandez's (1989) triadic measure, and the number of cutpoints per component. The alternative measures confirm the constraint results in table 6 . For the most conservative 1869-1913 network, mean brokerage scores equal $9.171(\mathrm{SD}=2.110)$ in the core and $.106(\mathrm{SD}=.013)$ in the periphery $(t=-6.231)$; the average number of cutpoints per component equals $57.981(\mathrm{SD}=63.129)$ in the core and $.064(\mathrm{SD}=.255)$ in the periphery $(t=-81.164)$.

${ }^{33}$ Size differences may explain greater reach in the core. By chance alone, bridging ties are more likely between large founding teams than between small teams. On average, founders in the core have 13 partners, whereas founders in the periphery have three partners during 1869-1913. However, we estimate network effects at the individual level, and it does not necessarily follow that a founder will initiate more ties to outsiders just because he is a member of a large founding team. Likewise, normalizing tie strength by team size requires some arbitrary cut-off to define when a tie exists. We opt for a nonparametric solution and control for founders' number of partners in our regressions. We also control for industry sectors, in particular finance, which mobilized more capital and attracted more founders than other sectors, especially in the network core.
} 


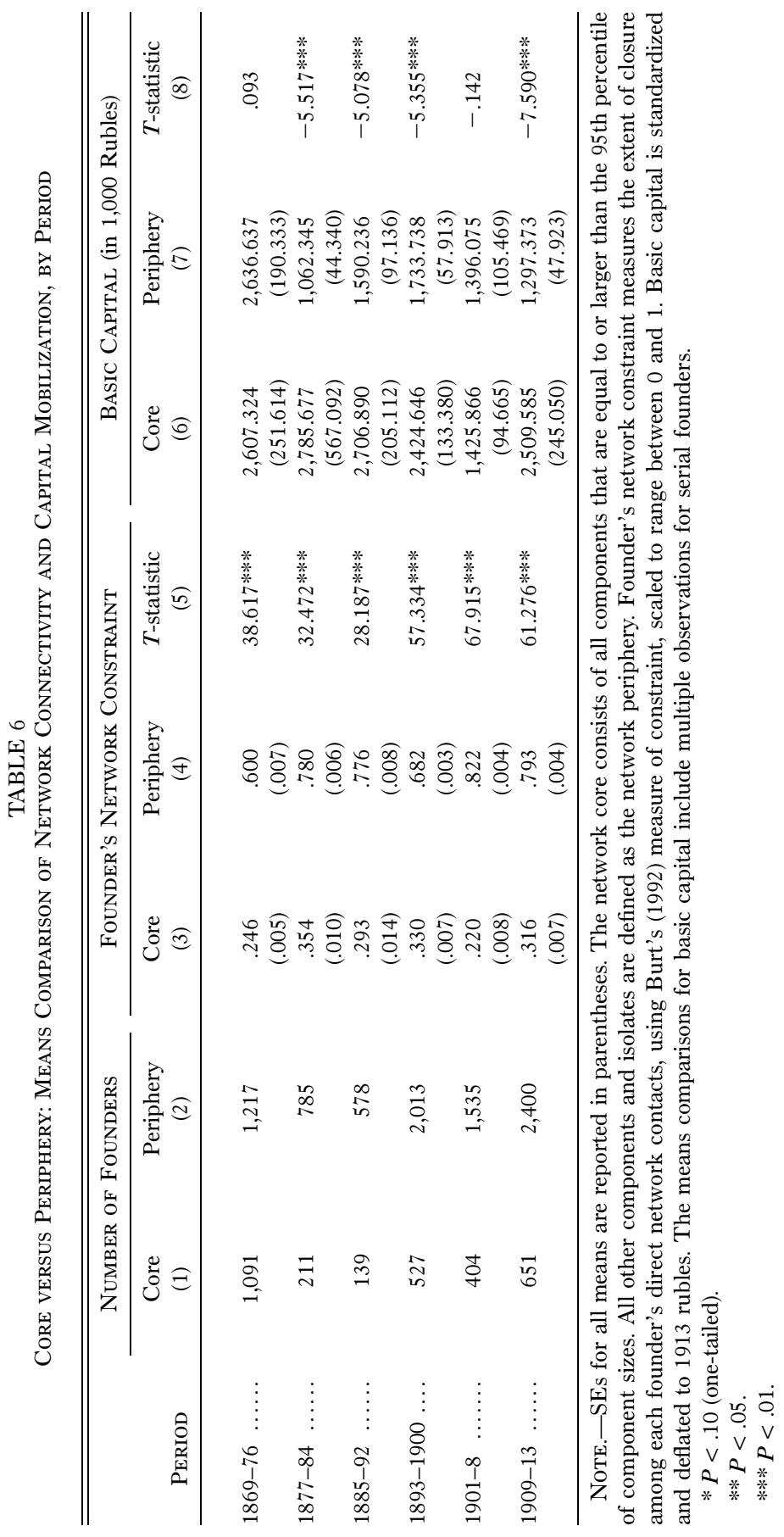


shows the expected negative effect on basic capital. Column 3 sets the differential influence of reputation in core and periphery aside and focuses on the main effects of constraint and reputation. Again, both a partner's reputation of previous success and the lack of network reach as measured by constraint have the expected effects on capital mobilization: having successful partners increased capital by about $15 \%$, whereas an increase in constraint by one standard deviation $(=.242)$ reduced the expected capital by about $6 \%$. In sum, these results delineate the social organizational foundations of entrepreneurship when the surrounding networks are fragmented. On a global scale, network reach across diverse groups in the core offers a clear advantage over the closed and isolated clusters of founders in the periphery. But, as noted above, where barriers to enter partnerships in the core are too high, it may become a locally rational strategy for peripheral founders to rely on closure and reputation for the mobilization of capital. ${ }^{34}$

To illustrate the bridging activities of brokers and their contribution to the pattern observed in the core, figure 3 shows the personal network of an exemplary entrepreneur who occupied a prominent mediating position. Timofei Savvich Morozov belonged to the leading industrialists of Moscow's entrepreneurial group. In politics, Morozov and his peers were ardent defendants of a romanticized pan-Slavic nationalism against the perceived threat of foreign competition and influence. Morozov was also closely tied to other prominent Muscovite merchant families through shared religious adherence to the Old Belief and several marriages of his large family (Rieber 1982). His diverse entrepreneurial activities in five different industries and four different provinces reflected his central mediating position in the cofounding network: the scores for both his constraint (.071) and his broker role between ethnic groups (298.350) place him in the top 5th percentile of network mediators in the core ${ }^{35}$ He made good use of this social capital as he served as the president of the Moscow

\footnotetext{
${ }^{34}$ Possible entry barriers to core positions included hinderances to mobility across ethnic boundaries that were built into rigid systems of ethnic stratification in some provinces or antisemitic policies lobbied for by slavophile industrialists (Weeks 1996; Kappeler 2001). But anecdotal evidence suggests that attitudes toward Jewish entrepreneurs were ambivalent: Muscovites urged the police to protect Jewish merchants from antisemitic rioters whenever the losses affected their own business; but when Jews were competitors, Russian merchants petitioned the government to expel them from Moscow (Owen 1981). Our quantitative evidence indicates that antisemitic sentiments were not strong enough to exclude Jews from core positions: in our panel data, $68 \%$ of the Jewish entrepreneurs still belonged to the network core, whereas only 59\% among non-Jewish (mostly ethnic Russian) founders held positions in the core $\left(\chi^{2}[d f=1]=7.6606 ; P=.006\right)$.

${ }^{35}$ For comparison, the mean constraint equals $.760(\mathrm{SD}=.242$; median $=.889)$, and the mean number of ethnic brokerage opportunities equals 72.344 ( $\mathrm{SD}=350.983$; median $=12.5$ ).
} 


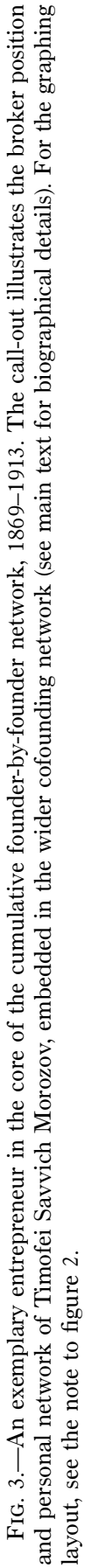


Exchange Society in the period 1870-76. The Exchange Society served as a political organization to unify the Moscow entrepreneurial elite and advocate their commercial interests, and thus it required considerable brokerage skills to bridge its diverse factions. Under Morozov's leadership, membership in the Exchange Society swelled to 1,500, indicating that it was capable of successfully representing diverse interest groups (Owen 1981; Rieber 1982).

\section{DATA LIMITATIONS AND SENSITIVITY ANALYSIS}

Founders and Investors

The RUSCORP database includes all founders who are listed in the company charters. As mentioned earlier, tsarist corporate law since 1836 prescribed that founders could not hold more than one-fifth of a company's initial share capital (Owen 1991a). Founders had to rely on outside investors for the remaining proportion of basic share capital. Share partnerships (about $35 \%$ of firms in our data) may have been an exception because they issued few and expensive shares so that their main founders may have also served as investors. All our estimations include controls for variation in organizational form. ${ }^{36}$ We also have data on the number and ruble value of shares that each corporation issued, and we include this information as control variables in our analysis. The size of the contribution that founders seek from outside investors will also depend on the type of business and the industry sector it operates in. We also control for these two variables in all our estimates of reputation and network position. The one piece of information we do not have is micro data on investor behavior. Hence, we cannot identify individual investors and how they allocated their contributions across different enterprises unless they also appear as founders of other companies in the database.

To what extent might this data limitation affect our findings? Investors may weave an alternative network through their joint sponsoring of multiple firms. Such joint investment ties would offer new opportunities for contact and thereby help to overcome the fragmentation we observe in the corporate cofounding network. The reasoning here is that we may fail to recognize the true extent of cohesion - rather than fragmentationin the corporate network because we are missing adequate information

\footnotetext{
${ }^{36}$ An alternative explanation for the positive relationship between a partner's past success and capital mobilization proposes that previously successful founders reinvested funds into their new ventures. This mechanism would apply primarily to share partnerships where founders also acted as main investors. But robustness checks of our results in table 3 , using interactions between past success and organizational form, yield no significant effects for partners with past success in share partnerships.
} 
on the networking activities of investors. However, the more investors commit themselves (and their capital) to an enterprise, the more we would expect them to seek a central position within that enterprise that permits them to influence its strategy. If investment ties are indeed so salient for corporate activities that they channel the formation of corporate networks, then the patterns of cofounding ties we observe in our data should reflect precisely the patterns of these investment relations. Direct historical evidence for our interpretation comes from contemporary Petersburg businessmen who stated that "in our country very often one and the same capitalist invests large amounts in several joint-stock enterprises on the condition, which is completely understandable, that he participate in the management of these enterprises" (quoted in Owen 1991a, p. 167).

\section{Alternative Sources of Affiliation}

Until now, our focus on cofounding ties has excluded alternative networks besides investor relations that merchant entrepreneurs in Russia may have relied on to bridge the structural holes that separated them within their business partnership networks. ${ }^{37}$ One interpretation considers that prior or concurrent ties established through kinship, neighborhood, or previous collaborations in the same industrial sector, among others, constrain or create opportunities for assembling founding team partnerships (Ruef, Aldrich, and Nancy 2003). If, for example, Russian entrepreneurs subscribed to taste-based discrimination against other ethnicities and preferred fellow Russians as partners instead, their cofounding networks should have become increasingly patterned along ethnic boundaries. In this scenario, relationships based on shared ethnicity or kinship would have bridged structural holes in cofounding networks (but may have given rise to ethnically homogenous clusters in the extreme).

Another interpretation emphasizes not the congruence of categorical affiliations and networks but cohesion through multiple crosscutting ties. Here, founders who are disconnected in one network setting may still be linked through alternative ties elsewhere (Gould 1995). For instance, the formation of some business partnerships may have cut across, and thereby helped to overcome, the diverse regional, ethnic, and religious rivalries that otherwise pitted entrepreneurial groups in tsarist Russia against each other (Rieber 1982; Joffe 1984; Owen 1991b). Whereas the first interpre-

\footnotetext{
${ }^{37}$ Antecedent collaboration in small businesses may have given rise to the corporate partnerships we observe and to unobserved cohesion. Unfortunately, we lack adequate data on small businesses because they did not require imperial chartering. However, if small-scale business partnerships did indeed lead to large corporations, then the corporate networks should reflect any cohesion created by these prior partnerships.
} 
tation identifies categorical homogeneity in separated local network clusters, the second interpretation emphasizes global cohesion based on diversity in categories and networks.

Figure 4 displays the extent of such overlap between cofounding networks and salient categorical affiliations within the network core and periphery over the entire $1869-1913$ period..$^{38}$ Recall that we define the network core as consisting of all partnership components that are equal to or larger than the 95th percentile of component sizes and consider all other components and isolates as belonging to the periphery.

Economic historians of late tsarist Russia have long noted that rivalries between industrial regions helped to prevent the emergence of a cohesive class identity among merchant entrepreneurs. Because the Russian empire was so expansive, geographic distance may have hindered collaboration across locales and amplified regional fragmentation (Rieber 1982; Joffe 1984; Owen 1991b). We have information on industrial sectors and the location of corporate headquarters for 4,172 companies active in the period 1869-1913. The first two comparisons to the left in figure 4 focus on the 1,694 interlocks among corporations and consider to what extent connected founding teams were located within the same industries and regions. For example, a link between a Saint Petersburg bank and a Moscow railroad company implies that their founders established businesses in at least two different regions and industries.

Sixty-six percent ( $=1,114$ ties) of the founding team interlocks reached across separate industrial sectors. ${ }^{39}$ Earlier, in the data section, we have already documented that the network positions of individual founders do not map directly onto geographic locations. Here, we likewise find that about 50\% ( $=840$ ties) of all corporate interlocks link teams across regional boundaries. The main result, then, is that neither geographic distance and regional rivalry nor industry sector boundaries prevented a considerable number of founding collaborations across these divisions. Consequently, neither was primarily responsible for the observed fragmentation.

\footnotetext{
${ }^{38}$ We have also calculated the proportion of within-category partnership ties separately for each of the six periods in table 4. The period-specific results confirm the pattern in fig. 4. We thus opt for the more parsimonious cross-sectional presentation. A single cross section is also conservative because it does not censor observations of bridges across categories.

${ }^{39}$ We may observe fragmentation and a small proportion of founders in the main component because we examine various industries at once and not a single organizational field as in other studies (Powell et al. 2005). Consequently, we should expect fragmentation because companies in similar industries cluster together with few bridges across clusters. The large proportion of cofounding ties across industrial sectors in fig. 4 suggests that little evidence exists for this concern.
} 


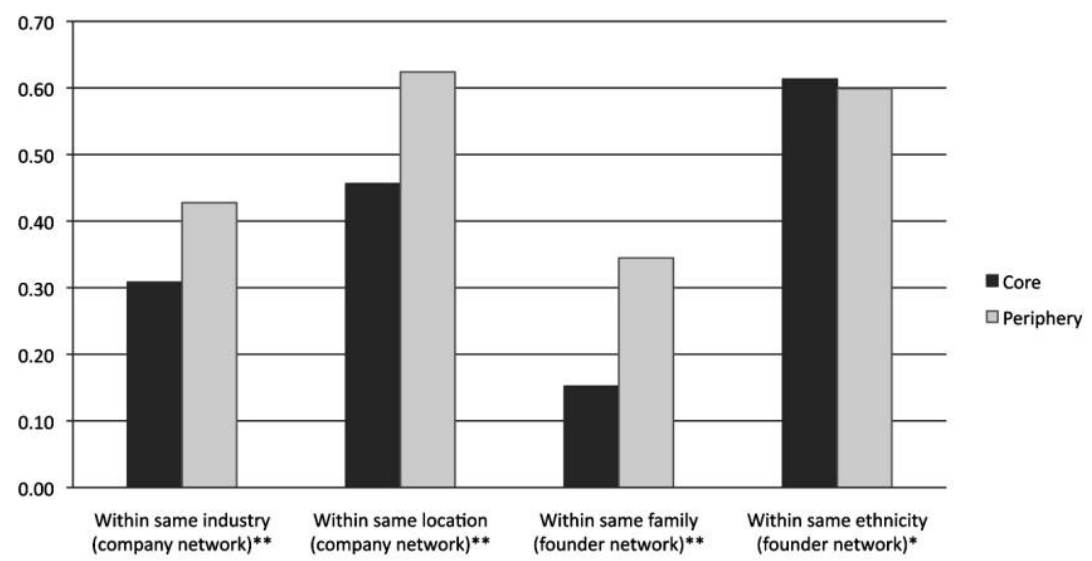

FIG. 4.-Comparison of network core and periphery: Proportion of cofounding ties within categories over entire period, 1869-1913. Significant differences in proportions: $* P<.05$, ** $P<.01\left(\chi^{2}[d f]=1\right)$.

Figure 4 further reveals that industrial and regional diversity was more common in the network core than in the periphery. Whereas $43 \%$ of all 484 cofounding ties within the periphery connected companies operating in the same industries, $69 \%$ of all 1,210 cofounding ties in the core linked companies in different industries. ${ }^{40}$ Similarly, regional segregation was significantly more pronounced in the periphery, where $62 \%$ of cofounding ties remained within the same location. In contrast, $54 \%$ of corporate interlocks within the core bridged across different regions. All differences in proportions are significant $(P<.010)$.

Our findings look similar for cofounding ties across kinship and ethnicity among individual entrepreneurs to the right in figure 4 . As in other historical contexts, family-owned firms and merchant dynasties played an important role in the Russian business world (Owen 1981; Rieber 1982; Adams 2005). In Moscow and elsewhere, "leading business families were

\footnotetext{
${ }^{40}$ Industry concentration seems unlikely to have generated the differences in connectivity between network core and periphery. We do find a significantly $(z=-28.707 ; P<.000)$ higher concentration in the finance sector among core founders ( $32 \%$ of foundings) than in the periphery $(11 \%)$, and our regression estimates reveal that foundings in the finance sector mobilized about $20 \%$ more capital than foundings in manufacturing (the comparison category). Banks certainly played a leading role in Russia's economic development (Crisp 1976; Owen 1991a). However, our endogeneity checks in the appendix demonstrate that capital needs did not dictate partner choice and were therefore unlikely to have shaped differences in network patterns. Similarly, a means comparison of network constraint does not offer strong evidence that founders in the finance sector (mean constraint $=.626 ; \mathrm{SD}=.319)$ enjoyed more broker opportunities than founders in other industries (mean constraint $=.698 ; \mathrm{SD}=.277)$.
} 
relatively old families, with a strong sense of continuity and personal pride in family achievements" (Ruckman 1984, p. 6). The first noteworthy founder-level result in figure 4 indicates, however, that kinship is the least salient category for creating business partnerships. In the periphery, only $35 \%$ of cofounding ties connect founders who share the same last name. ${ }^{41}$ Once again, this result contrasts significantly with the network core where merely $15 \%$ of partnership ties formed among kin.

Equally crucial for merchant entrepreneurs and for tsarist Russia in general were the boundaries that separated the diverse ethnic groups the empire was composed of (Weeks 1996; Kappeler 2001). ${ }^{42}$ Self-selection, fueled by ethnic prejudice, was evident such that merchant entrepreneurs often preferred co-ethnic business partners (Rieber 1982; Owen 1991b). As noted earlier, increasingly repressive legislation against foreign entrepreneurs and ethnic minorities, especially against Jews, restricted many corporate activities to ethnic Russians (Rogger 1986; Nathans 2002). The proportions reported in figure 4 suggest that ethnicity was indeed a correlate of corporate partnerships: about $60 \%$ of cofounding ties linked entrepreneurs who shared the same ethnic origin. Yet, the difference in diversity between core and periphery that is so substantial for all other categories seems less clear with respect to ethnicity. ${ }^{43}$

\footnotetext{
${ }^{41}$ Systematic kinship information is not available for all founders. We therefore coded kinship ties through a careful matching on surnames using both a name recognition algorithm and case-by-case inspection. We then identified components in this kinship network as our proxy for families. This coding is obviously a proxy, but the bias can be in both directions: not all founders who share the same surname are necessarily relatives, but relatives need not share the same surname. Matching on last names may also obscure Russification of ethnic minorities (Weeks 1996; Kappeler 2001; Brower 2003). However, our main point is that business partners were less likely to be relatives than expected, based on the lack of similarity in names. Our result is in fact conservative: if we were able to correct the Russification bias, then the names of ethnic minority members that currently look similar to Russian names will differ from those Russian names. Consequently, there would be even less similarity in last names among business partners than we observe.

${ }^{42}$ Ethnicity and our kinship coding are strongly correlated: over all six period networks, $92 \%$ of kinship ties linked co-ethnic founders, on average $(\mathrm{SD}=3.1 \%$; $\max =95.7 \%$, $\min =87.5 \%$ ).

${ }^{43}$ Until the end of the third period (1885-92), co-ethnic partnership ties were more prevalent in the periphery than in the core, revealing a pattern similar to within-industry, within-location, and kinship ties in fig. 4 . The tsarist government's policies against ethnic minority entrepreneurs became particularly severe by the fourth period (1893-1900). This shift toward more severe restrictions coincided with an increase in co-ethnic partnership ties in the network core, from $44 \%$ of all partnership ties in $1885-92$ to $68 \%$ in $1893-$ 1900. In the periphery, the proportion of co-ethnic ties decreased from $67 \%$ to $60 \%$, possibly because Russian founders who wished to continue their partnerships with ethnic minority entrepreneurs had to move from prominent network core positions to peripheral locations that were less exposed to government sanctions.
} 
In sum, these results show that the extent of fragmentation we identified earlier is not just a by-product of our focus on cofounding partnerships. Certainly, alternative ties and group memberships may have bridged the structural holes and supported cohesion within the cofounding network. Such alternative bridges were significantly more common within the network core than within the periphery. It was primarily in the core that founders from diverse backgrounds-different regions, industries, and families-formed business partnerships with each other, and thereby contributed to social cohesion. Ethnicity, in contrast, was a less likely source of global cohesion. In both core and periphery, founders were more likely to eschew partners who did not share their ethnic origins, a selection that contributed to fragmentation along ethnic boundaries.

Finally, the majority of founders (68\% in the entire 1869-1913 window) were located in the periphery of the cofounding network, and here their dominant strategy of partnership choice was homophily, not diversity. They preferred business partners who shared their background, a strategy that reinforced local closure but undermined the global cohesion that would enable them to reach distant and diverse clusters of entrepreneurs. In the absence of reliable public institutions to protect property rights and contract commitment, such reliance on trustworthy neighbors and one's family may have made perfect sense for entrepreneurs in the periphery. But the unintended consequence of this homophily strategy in their local circles was the reproduction of precisely the network fragmentation their strategy was designed to cope with in the first place. One obvious question is why the structural holes between components were so persistent over time. If network reach was really so beneficial, why do we observe so little change toward cohesion over time? Our evidence suggests that a local preference for similar business partners was one, but certainly not the only, important influence that blocked substantial changes in the network structure.

\section{Foreign and Ethnic Minority Entrepreneurs}

One may wonder to what extent the presence or absence of foreign founders in our data set influences our findings. The role of foreign entrepreneurship within late tsarist Russia has long been recognized in the literature (McKay 1970; Rieber 1982; Carstensen 1983, 1984). But, as we emphasize in these pages, arbitrary decisions by the tsarist administration often hindered the entrepreneurial activities of foreigners. Still, within the limits prescribed by these restricting policies, foreigners could and did become partners on corporate founding teams (Owen 1991a, 1992). Within the sample of 1,077 serial entrepreneurs that enter our regressions in tables 3 and 5, we were able to identify 58 of these observations as foreign founders, using the information on citizenship in the RUSCORP database. 
Because we have so few non-Russian citizens, we briefly summarize the robustness checks we undertook. Foreign founders in our sample do not occupy significantly different positions in the corporate network than their Russian peers. Sixty percent among foreign founders belong to the network core, which contrasts little with the $63 \%$ core members among Russian entrepreneurs $\left(\chi^{2}=.1788, P=.672\right)$. Virtually no difference exists in the average network constraint between foreigners (constraint $=$ .6766 ) and Russians (constraint $=.6765 ; t$-value $=-.0014$ ). Foreign founders are engaged in more brokerage opportunities between different ethnic groups (mean brokerage score $=244.3$ ) than their Russian counterparts (mean brokerage score $=126.3$ ), but not significantly so ( $t$-value $=-1.2809)$. Likewise, controlling for foreigners has little impact on our multivariate results. We replicated all capital regressions with an added covariate for foreign citizenship (the number of observations is too small to distinguish between nationalities). As suggested in the literature, foreign entrepreneurs display a significant positive effect on capital mobilization when they are added to the specifications in columns 1 and 2 in table 3 (the coefficients equal .246 [SE $=.102]$ and .264 [SE $=.121]$ ). Controlling for foreign citizenship of founders in table 5 also yields significant and positive impacts on capital (the coefficients are .256 [SE $=.120]$ in col. $1, .242[\mathrm{SE}=.120]$ in col. 2, and $.242[\mathrm{SE}=.120]$ in col. 3). But the important point here is rather that all of our main effects-reputation and network position—on capital mobilization remain virtually unchanged in direction, magnitude, and significance.

As with foreign citizens, restrictive policies of the Russian state toward ethnic minority entrepreneurs shifted over time. To what extent did the policy shifts influence entrepreneurial networks? Our results in appendix tables A1 and A2 demonstrate that increasingly severe discriminatory policies of the tsarist state did have a clear effect. For example, some of the most stringent policies restricted the rights of Jewish entrepreneurs, which significantly reduced the formation and continuation of partnership ties between ethnic-Russians and Jews. ${ }^{44}$ By contrast, the results of our network analyses show that the overall pattern of the entrepreneurial network remains largely unchanged over the entire period. Combining both findings suggests that state policies primarily affected what kind of persons (their ethnic and religious origins) these entrepreneurs could choose as their partners, but also that policy shifts seem to have done little to change the way in which entrepreneurial networks were arranged. Put differently, the structural properties of entrepreneurial networks re-

\footnotetext{
${ }^{44}$ Data limitations make an analysis of discriminatory policies much more tractable for Jews than for other minority groups.
} 
mained intact, but the state was able to influence who could occupy the individual positions within it.

\section{DISCUSSION}

\section{Summary of Results}

The motivation for our analysis has been a twin challenge for emergent economies. In the absence of sufficiently developed public institutions to enforce contract commitments and property rights, reputation and the control benefits of cohesive networks may provide private-order substitutes (Fafchamps 2004; Greif 2006). However, industrial growth and firm development also require access to diverse capital sources, which necessitates far-reaching networks to discover funding opportunities. The problem is that these two entrepreneurial agendas pursue different strategieseither a focus on enforcing contract commitments or a focus on locating capital and other resources. Likewise, their social organizational prerequisites differ-they require either networks that are cohesive enough to permit effective monitoring and sanctioning or networks that are sufficiently widespread so that exchange partners may identify potential capital sources. How, then, is efficient economic organization possible under such conditions?

Our historical setting of late imperial Russia is such a case, where weak public institutions, arbitrary governance, and fragmentation into competing ethnic, religious, and regional interest groups characterized an emergent economy (Gatrell 1995; Kappeler 2001). We have examined rich historical evidence on corporate entrepreneurship, particularly how varying patterns of partnership networks offered different opportunities for the allocation of basic capital. The evidence indicates that reputationbased arrangements were most effective in small and isolated peripheral components, composed of founders who shared similar ethnic, kinship, and regional origins. Here network closure and homophily combined to yield capital benefits from reputation. Yet, within the wide-spanning network core with its diverse membership, brokerage and bridging opportunities were more effective for capital mobilization than reputation effects. Finally, we also find that core entrepreneurs tended to be more successful in raising basic capital than their competitors in the periphery.

\section{Lessons from Historical Corporate Networks}

Our argument applies primarily to similar settings where states are either too weak to sufficiently uphold contract enforcement and property rights as public goods or where governments grant property rights only selec- 
tively to particular ethnic, regional, or religious interest groups and pursue policies that exclude members of other groups (Haber et al. 2003). A comprehensive comparison with the role of entrepreneurial networks in other historical or contemporary settings is beyond the scope of the present study. Nevertheless, two aspects of the relationship between such networks and their institutional environment are worth emphasizing because evidence from industrialization in other settings echoes developments we identified in our historical case.

First, we may expect that variation in institutional conditions across countries yields corresponding differences in the organization of entrepreneurial networks. Yet, recent studies of the historical development of such networks in the United States and other Western economies have also found evidence that these networks varied substantially in their cohesiveness - even when they were located in the same industrial regions within countries and thus faced similar challenges of economic development (Morck 2005; Safford 2009). The important implication here is that the spurts of technological advances that are so characteristic of industrializing economies may not be sufficient to push the entire organization of corporate networks toward the more cohesive patterns we observe in the core of the Russian network. That industrialization alone may not necessarily lead to an efficient organization of entrepreneurial networks explains to some extent why we observe so little change in the Russian corporate networks despite the extensive industrialization of the economy around the turn of the century. The lesson from the present study and comparable cases is that, without reliable market-supporting institutions, the demand persists for the tightly knit and reputation-based local clusters we find in the periphery of the Russian network (Fafchamps 2004). Evidence from other economies that experienced their initial industrial development at about the same time as Russia supports this inference. Recent work on interlocking boards of joint-stock companies in Latin America, for example, shows that business networks in Mexico formed around dense and exclusive personal connections that substituted for the reliance on the formal legal system. In contrast, in Brazil, formal institutions existed that promoted financial markets and facilitated the allocation of capital, and Brazilian corporate networks consisted of connected yet widespread clusters (Musacchio and Read 2007).

These comparative insights and our findings suggest that the extent to which market-supporting institutions exist is at least as critical for the organization of corporate networks and economic growth as the more technological aspect of industrial development (Mokyr 2009). Stable formal institutions are so important for efficient economic organization because "a market meant much more than just effective demand, or the use of money in exchange, or even good transport facilities, but also confidence 
in the stability of the currency, a proper credit organisation, a system of reliable and enforceable law, and knowledge which came from the experience of the operation of market forces" (Crisp 1976, p. 218). In general, with the provision of such formalized institutions, we would expect a movement toward the cohesive yet wide-reaching networks we find in the Russian network core. At the same time, we would expect the reliance on close-knit and reputation-based network circles to become less salient for successful entrepreneurship.

The second aspect of entrepreneurial networks we emphasize concerns how varying patterns of corporate relationships relate to economic and political outcomes. Our evidence reveals that the core networks, composed of diverse overlapping affiliations, had a clear performance advantage over the closed and relatively homogeneous clusters in the network periphery in Russia. This finding indicates that the success of entrepreneurs is contingent on the particular arrangement of the opportunity structure in which they are embedded. ${ }^{45}$ Again, we find parallel developments in other historical instances of regional industrial development. For example, tracing the roots of industrial development as far back as the mid-18th century, Safford (2009) documents that differences in their social structures led communities in the American Rust Belt to respond differently to the challenges of a postindustrial world. Responses were successful in communities whose multiple and crosscutting business, political, and civic networks enabled cooperation between various interest groups that otherwise would have been divided by their regional, ethnic, and class-based alignments. In contrast, neighboring communities that lacked such crosscutting networks eventually fragmented and fell behind in regional renewal.

These conditions resemble our finding that the relationships of corporate networks in Russia did not map directly onto locations in the economic and political geography of the empire but instead crosscut their corresponding ethnic and socioeconomic boundaries. This result may be of substantive importance to those interested in the potential for economic and political cooperation within such multiethnic policies as imperial Russia. Historians have long noted the absence of a rising bourgeoisie in late imperial Russia. In contrast to Western Europe, the middle classes in Russia were unable to turn their economic power into political influence. To explain this lack of political engagement, historical interpretations have invoked several fissures separating Russian merchant entrepreneurs: ethnic differences, religious segregation, and rivalries between industrial

\footnotetext{
${ }^{45}$ This insight is not limited to economics. Recent research in political sociology shows that the crosscutting of multiple networks facilitated political mobilization (e.g., Gould 1995).
} 
regions in addition to inequality in social ranks (Rieber 1982; Clowes et al. 1991). This is not the place for a detailed account of middle-class politics in Russia before the October Revolution. Still, our findings suggest that at least the various intersecting relationships that formed the network core may have offered a promising social structural basis for the formation of new identities that bridged existing ethnic, regional, and religious divisions.

\section{APPENDIX}

\section{Basic Capital and Economic Performance}

One general concern is how basic capital at the time of founding relates to later corporate performance. Systematic information on conventional indicators of performance such as labor force size, the value of assets and stocks, and annual sales figures or profits is either unavailable or rudimentary at best. As an alternative measure of performance, entries in corporate directories for the years 1869, 1874, 1892, 1905, and 1914 allow us to compare the survival rates of corporate foundings we classified as successful and those we coded as nonsuccessful. The RUSCORP database does not have this survival information for every company in our sample, but we were able to obtain it for 1,301 successful founding teams and for 1,096 nonsuccessful ones, all established between 1869 and 1913. For example, a company founded in 1870 is considered to have survived until 1874 if it is listed in the corporate directory of that year. The company survived further until 1892 if it is also listed in the 1892 directory. If it is not listed in the 1905 directory, it is coded as having failed by 1905 . The information is not perfect because we cannot specify in what year between 1892 and 1905 the company failed. Most likely, this discrete-time measure of failure will bias corporate lifetime toward longer survival, but the bias is the same for successful and nonsuccessful foundings. Figure A1 plots the resulting Kaplan-Meier survival estimates.

Clearly, our classification of success based on capital mobilization is a meaningful indicator of future economic performance: successful corporate foundings survived at a significantly higher rate than nonsuccessful foundings $\left(\chi^{2}=10.52, P=.0012\right)$. If anything, our result is conservative: the majority of foundings occur in later periods, and opportunities for failure become fewer, the closer the time of founding gets to 1914 (the censoring year). Hence, in the first $10+$ years after founding, the failure rates for the two categories are likely to appear more equal than they really are. We therefore relied on the log-rank test to compare the equality of survivor functions because it emphasizes differences toward the end of analysis time. 
Still, some economic historians reason that the capital recorded in charters was a nominal rather than a real value. Crisp (1976) and Carstensen (1983) argue that expansions of capital did not reflect real investments but efforts to reduce a company's tax rate, especially after tax increases in the period 1906-8: "In 1906 the progressivity of the tax was increased sharply, the marginal rates reaching 24 percent on profits that exceeded 16 percent of nominal capital. To reduce taxes, a company only needed to increase its capital" (Carstensen 1983, pp. 143-45). We find no evidence that supports this argument: throughout all specifications in table 3, none of the indicators for 1906 and later years show a significant positive effect on basic capital, as one would expect if founders systematically evaded taxes.

Even if we exclude tax evasion, the capital recorded in the charters may not express real values of successful corporations but stock-jobbing by unscrupulous founders and speculators. Again, our regressions offer robust evidence that a reputation of past success is a strong predictor of future success. If large capitalizations merely indicated embezzlement, then we should not find that the same founders were repeatedly able to win investors for their projects, assuming that investors remembered past fraud.

\section{Endogeneity Checks: Discriminatory Legislation and Partner Choice}

Does the recruitment of reputable partners increase the amount of basic capital, as our reasoning suggests, or do capital requirements for an intended enterprise dictate the choice of founding partners who are able to raise sufficient funds? To disentangle the causal sequence, we first identify an instrumental variable that significantly constrained the choice of business partners but had no systematic impact upon the size of capital mobilized. In particular, we rely on the introduction of arbitrary legislations whereby the tsarist government discriminated against foreign and especially Jewish entrepreneurs. We demonstrate that these discriminatory policies were systematically related to variation in the choice of partners. In a second step, we then compare the effect of successful founding partners on the amount of capital raised before and after the introduction of these arbitrary policies. The main idea is that, once they were enacted, these legal discriminations severely limited the kinds of partners one could choose. Consequently, whatever capitalization requirements existed, they could not have been primarily responsible for the choice of business partners.

We consider the cumulative effect, by 1899, of successive government restrictions on Jewish (and often Polish) corporate activities in the Russian 
Empire (detailed in Owen 1991a, pp. 122-49). ${ }^{46}$ Between 1864 and 1890 alone, a series of increasingly restrictive legal regulations were enacted that prohibited Jewish entrepreneurs from leasing or owning landed property and from taking up residence outside the Jewish Pale of Settlement. ${ }^{47}$ Corporate landholding also became restricted to prevent Jews from acquiring land indirectly through company shares. From 1892 onward, Jews were denied property rights pertaining to mining areas in Poland, and by 1899 most corporate managerial positions were closed to Jews.

Table A1 demonstrates that these discriminatory policies significantly reduced partnership ties between ethnic-Russians and Jews (coding based on the ethnic classification of founders in the corporate charters). In Russia at large, the percentage of ties that Russians maintained with Jewish partners dropped significantly from $7.4 \%$ before 1899 to merely $4.1 \%$ afterward. The percentage decreased despite a $60 \%$ increase in the number of potential Jewish partners. The decline in choosing Jewish founding partners was even more pronounced in locations directly affected by the discriminatory laws: the percentage of partnership ties that Russian founders maintained with Jews were significantly reduced by nearly a half, from about $17 \%$ before 1899 to about $9 \%$ afterward.

Table A2 demonstrates that other Russian founders could not adequately compensate the loss of successful Jewish partners. In the entire Russian empire, about $10 \%$ of Jewish founders were involved in previously successful foundings before 1899, using our definition of success. In contrast, merely $5 \%$ of the Russian founders in our sample can be considered successful before 1899. This significant difference disappeared with the full impact of discriminatory policies. After 1899, the proportion of successful Jewish founders was halved to $5 \%$ whereas the increase of successful Russian founders was marginal, by less than $1 \%$. The results are nearly identical for those locations directly affected by the discriminatory policies. Both tables document that state-sponsored discrimination did indeed shape Russian founders' choice of business partners and that it thus provides a suitable instrument for our robustness analysis.

In table A3, we apply the same OLS specifications as in table 3. The

\footnotetext{
${ }^{46} \mathrm{We}$ also attempted more fine-grained estimations of before/after effects of these policies, using more than one point in time. Unfortunately, the data do not leave us with sufficient numbers of observations in some periods to reliably estimate policy impacts.

${ }^{47}$ The Pale of Permanent Jewish Settlement (cherta postoiannoi evreiskoi osedlosti) bounded the territory to which the Russian state confined Jewish residence until 1917. It included the empire's 15 western provinces (roughly today's Lithuania, Belorussia, and Ukraine) plus the Kingdom of Poland. Few Jews were permitted to reside outside the Pale. The 1897 census estimated 5.2 million Jews in the Russian empire, about 4\% of the entire population, making them the largest non-Slavic and non-Christian group (Rogger 1986; Nathans 2002).
} 


\section{American Journal of Sociology}

difference is that we compare the estimates before and after the full impact of discriminatory policies in those locations that were directly affected by them. The post-1899 estimates take into account that these policies significantly constrained partner choices, which in turn permits us to identify the effect of reputable and successful partners on the mobilization of capital. ${ }^{48}$

The results in table A3 confirm our inferences from table 3: joining with a reputable and successful partner still significantly increases the amount of basic capital. The result remains robust when we take legal restrictions on partner choice into account, indicating that variation in partnering with successful founders is largely exogenous to capital requirements. The magnitude of these estimates increases slightly after 1899, possibly because those previously successful founders that were still available as partners made even more of a difference in capital mobilization than before. A similar logic may explain the strong impact of continued partnerships in column 4: if the choice of partners becomes increasingly restricted, then any opportunity to continue a working partnership will be appreciated.

\footnotetext{
${ }^{48}$ Ideally, we would use a two-stage specification, but founders in our data joined with multiple partners in varying founding teams and years. Consequently, legal restrictions applied to some, but not all, of their partners. It thus remains unclear which partners should be selected to specify the IV model.
} 


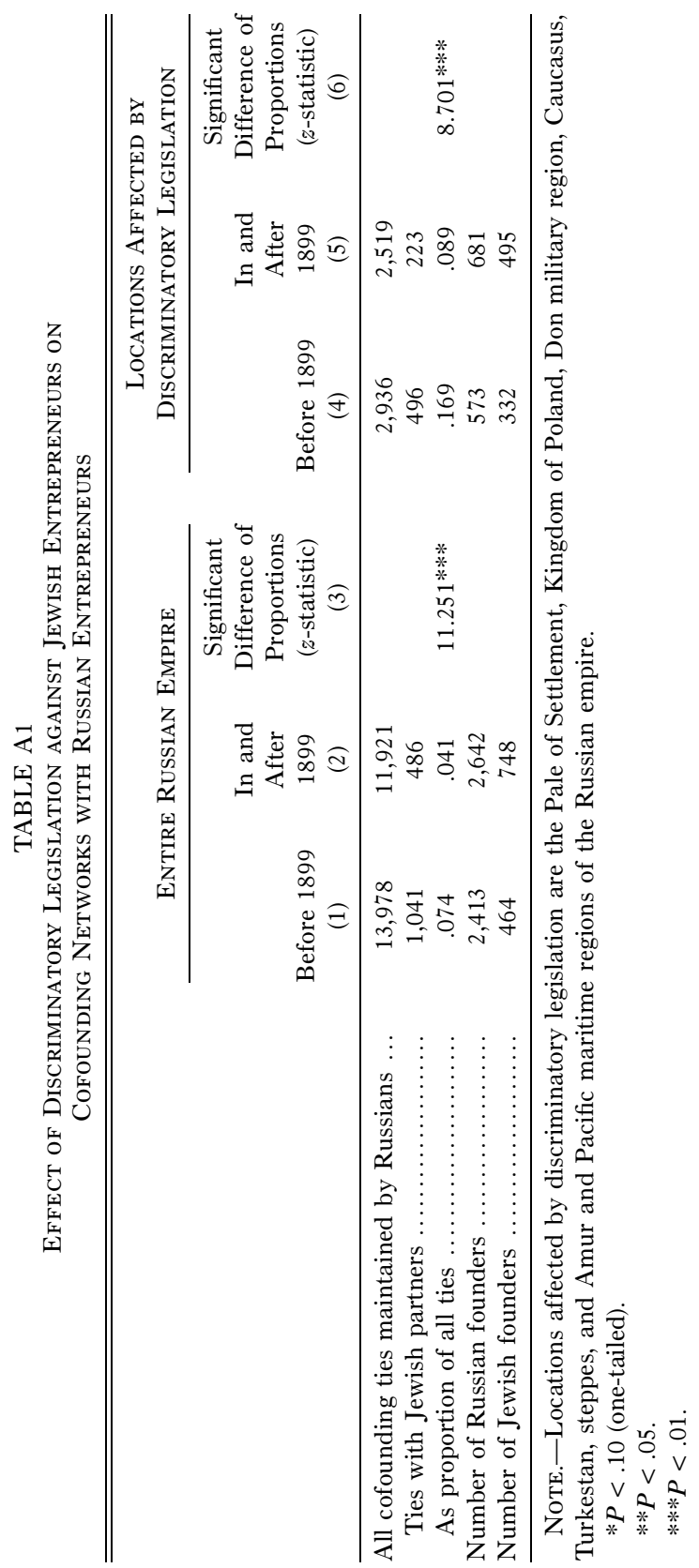




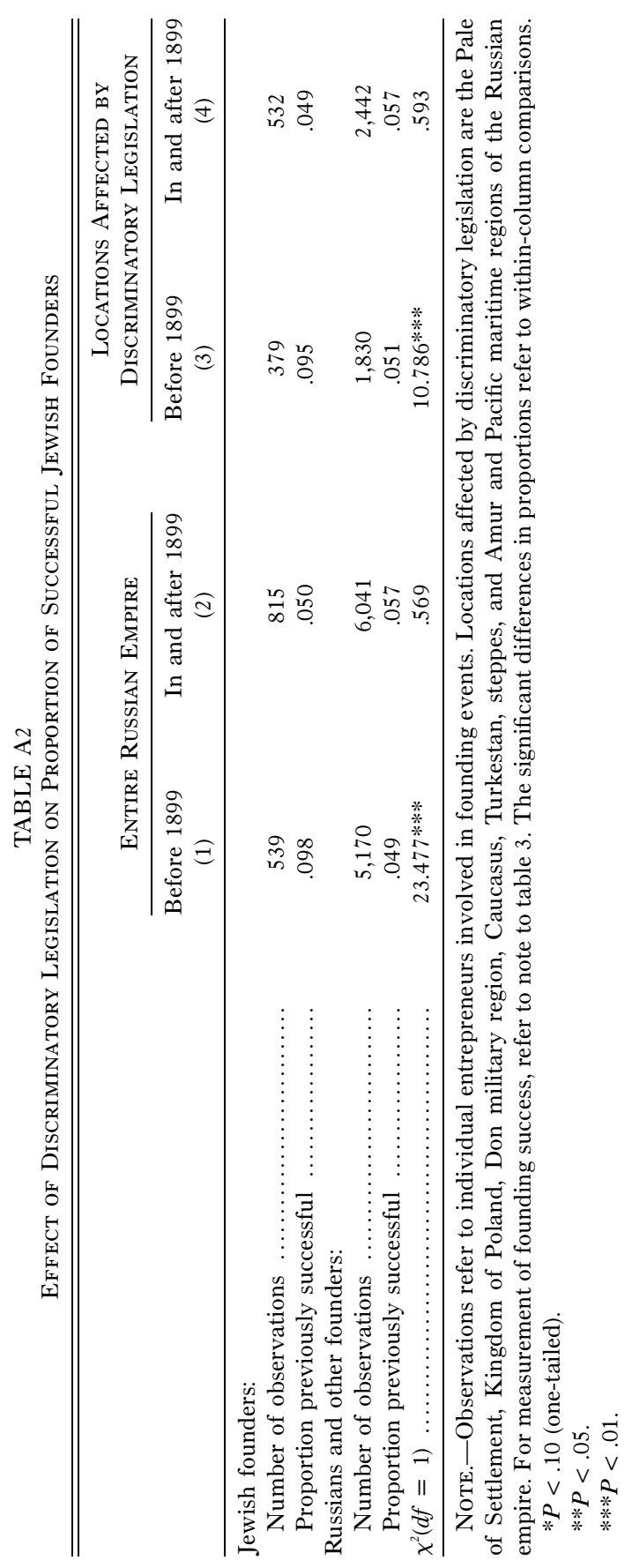




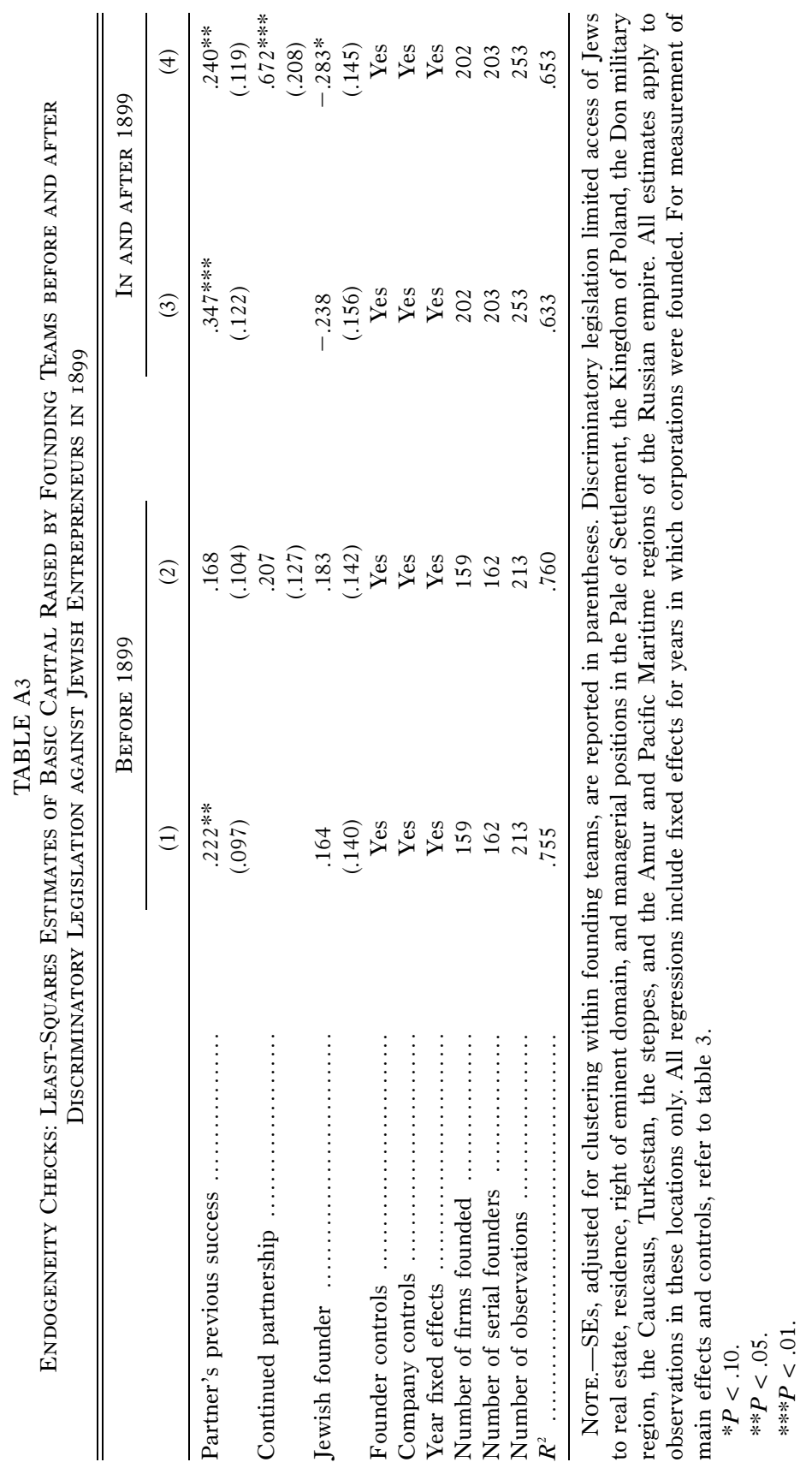




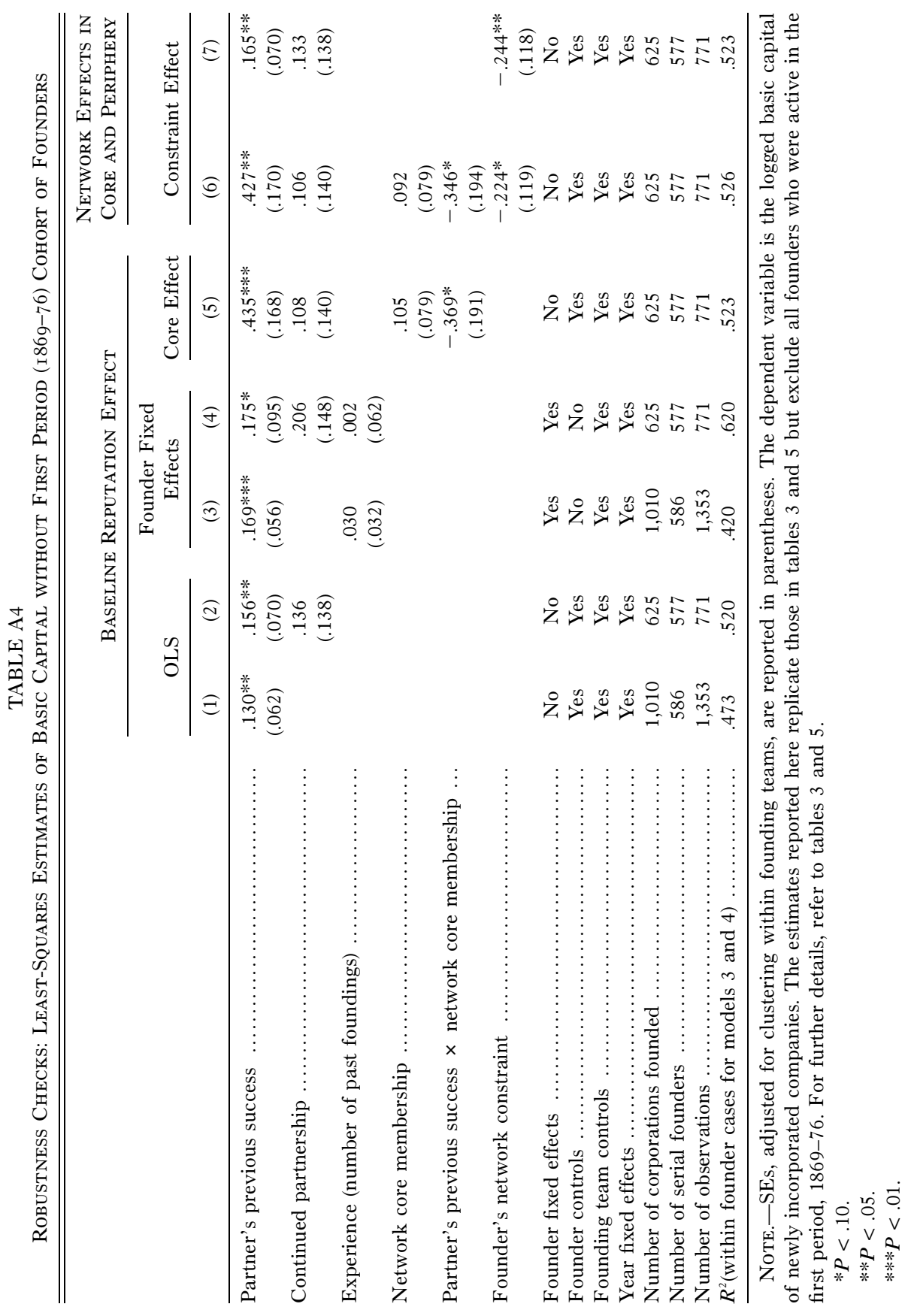




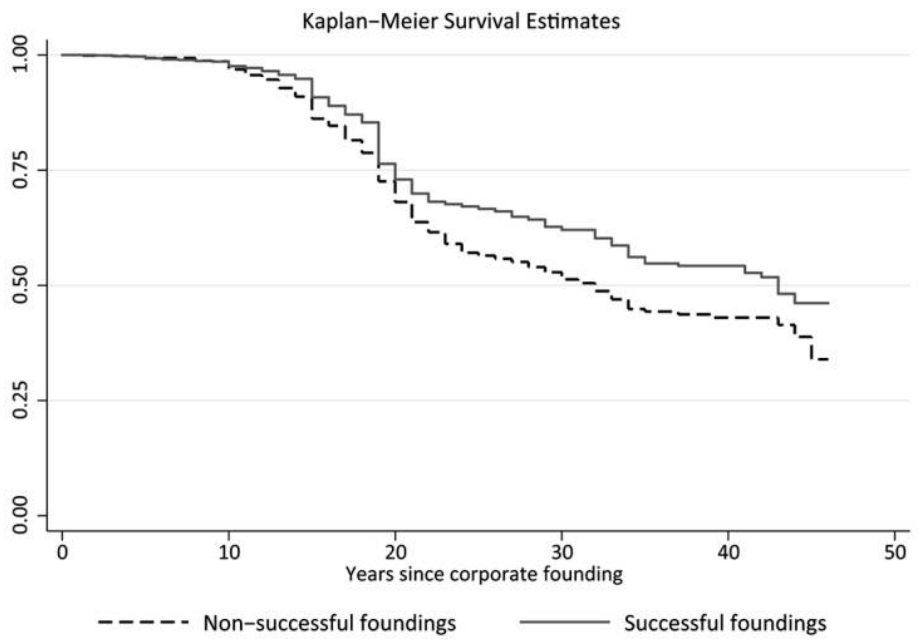

Fig. A1.-Basic capital as indicator of economic performance. The graph compares survival rates for corporate foundings coded as successful (their basic capital is equal to or exceeds the median capital for all other corporations founded in the same industry, region, and decade) and foundings coded as nonsuccessful (their basic capital is below the median capital). $N=1,096$ nonsuccessful foundings (227 failures) versus $n=1,301$ successful foundings (223 failures). Log-rank test of equality of survivor functions: $\chi^{2}(d f=1)=10.53$ $(P=.0012)$.

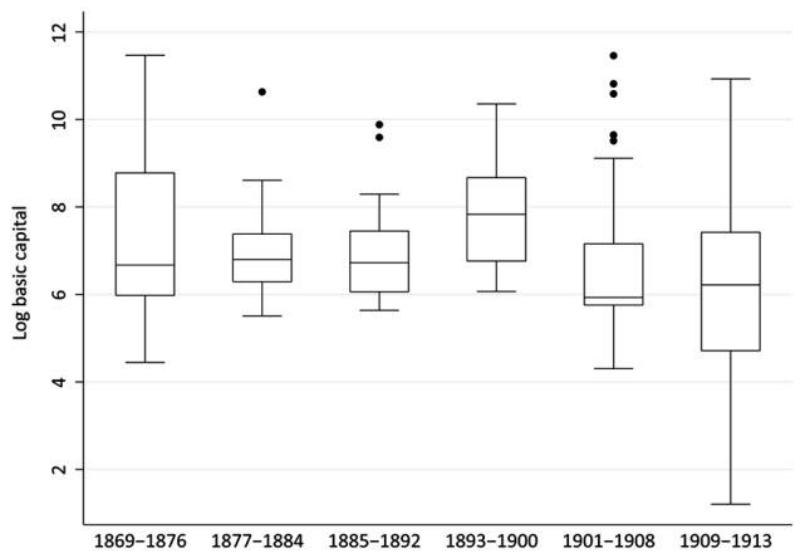

FIG. A2.-Distribution of logged basic capital of corporate foundings in the transportation sector, by period. The figure plots the distribution of basic capital in the transportation industry, including railways and river shipment. The $Y$-axis represents logged basic capital amounts, standardized and deflated to 1913 rubles. The $X$-axis refers to the periodization we use in our network analysis (see main text). The boxes enclose the interquartile range. The lines within the box areas represent median values. The whiskers and dots represent outlying observations that extent beyond the 75 th and 25 th percentiles. 


\section{American Journal of Sociology}

\section{REFERENCES}

Adams, Julia. 2005. The Familial State: Ruling Families and Merchant Capitalism in Early Modern Europe. Ithaca, N.Y.: Cornell University Press.

Bassin, Mark. 1999. Imperial Visions: Nationalist Imagination and Geographical Expansion in the Russian Far East, 1840-1865. Cambridge: Cambridge University Press.

Brower, Daniel. 2003. Turkestan and the Fate of the Russian Empire. New York: Routledge.

Burt, Ronald S. 1992. Structural Holes: The Social Structure of Competition. Cambridge, Mass.: Harvard University Press.

- 2005. Brokerage and Closure: An Introduction to Social Capital. New York: Oxford University Press.

Carstensen, Fred V. 1983. "Foreign Participation in Russian Economic Life: Notes on British Enterprise, 1865-1914." Pp. 140-58 in Entrepreneurship in Imperial Russia and the Soviet Union, edited by Gregory Guroff and Fred V. Carstensen. Princeton, N.J.: Princeton University Press.

- 1984. American Enterprise in Foreign Markets: Studies of Singer and International Harvester in Imperial Russia. Chapel Hill: University of North Carolina Press.

Clowes, Edith W., Samuel D. Kassow, and James L. West, eds. 1991. Between Tsar and People: Educated Society and the Quest for Public Identity in Late Imperial Russia. Princeton, N.J.: Princeton University Press.

Coleman, James S. 1990. Foundations of Social Theory. Cambridge, Mass.: Harvard University Press.

Crisp, Olga. 1976. Studies in the Russian Economy before 1914. London: Macmillan.

Eklof, Ben, John Bushnell, and Larissa Zakharova, eds. 1994. Russia's Great Reforms, 1855-1881. Bloomington: Indiana University Press.

Ellickson, Robert C. 1991. Order without Law: How Neighbors Settle Disputes. Cambridge, Mass.: Harvard University Press.

Fafchamps, Marcel. 2004. Market Institutions in Sub-Saharan Africa. Cambridge, Mass.: MIT Press.

Gatrell, Peter. 1986. The Tsarist Economy, 1850-1917. London: Badsford.

- 1995. "Economic Culture, Economic Policy and Economic Growth in Russia, 1861-1914." Cahiers du monde Russe 36:37-52.

Gerschenkron, Alexander. 1962. Economic Backwardness in Historical Perspective. Cambridge, Mass.: Harvard University Press.

Gould, Roger V. 1995. Insurgent Identities: Class, Community, and Protest in Paris from 1848 to the Commune. Chicago: University of Chicago Press.

Gould, Roger V., and Roberto M. Fernandez. 1989. "Structures of Mediation: A Formal Approach to Brokerage in Transaction Networks." Sociological Methodology 19:89126.

Gregory, Paul R. 1982. Russian National Income, 1885-1913. Cambridge: Cambridge University Press.

- 1994. Before Command: An Economic History of Russia from Emancipation to the First Five-Year Plan. Princeton, N.J.: Princeton University Press.

Greif, Avner. 2006. Institutions and the Path to the Modern Economy: Lessons from Medieval Trade. Cambridge: Cambridge University Press.

Guroff, Gregory, and Fred V. Carstensen, eds. 1983. Entrepreneurship in Imperial Russia and the Soviet Union. Princeton, N.J.: Princeton University Press.

Haber, Stephen, Armando Razo, and Noel Maurer. 2003. The Politics of Property Rights: Political Instability, Credible Commitments, and Economic Growth in Mexico, 1876-1929. Cambridge: Cambridge University Press.

Joffe, Muriel. 1984. "Regional Rivalry and Economic Nationalism: The Central In- 
dustrial Region Industrialists' Strategy for the Development of the Russian Economy, 1880s-1914." Russian History/Histoire Russe 11: 389-421.

Kahan, Arcadius. 1989. Russian Economic History: The Nineteenth Century, edited by Roger Weiss. Chicago: University of Chicago Press.

Kappeler, Andreas. 2001. Rußland als Vielvölkerreich: Entstehung-Geschichte-Zerfall [Russia as a multiethnic empire: Origins—history—demise], rev. ed. Munich: Beck

Kossinets, Gueorgi, and Duncan J. Watts. 2009. "Origins of Homophily in an Evolving Social Network." American Journal of Sociology 115:405-50.

Maurer, Noel, and Tridib Sharma. 2001. "Enforcing Property Rights through Reputation: Mexico's Early Industrialization, 1878-1913." Journal of Economic History 61:950-73.

McKay, John P. 1970. Pioneers for Profit: Foreign Entrepreneurship and Russian Industrialization, 1885-1913. Chicago: University of Chicago Press.

Mokyr, Joel. 2009. The Enlightened Economy: An Economic History of Britain, 17001850. New Haven, Conn.: Yale University Press.

Moody, James. 2004. "The Structure of a Social Science Collaboration Network: Disciplinary Cohesion from 1963 to 1999." American Sociological Review 69:213-38.

Moody, James, and Douglas R. White. 2003. "Structural Cohesion and Embeddedness: A Hierarchical Concept of Social Groups." American Sociological Review 68:10327.

Morck, Randall K., ed. 2005. A History of Corporate Governance around the World. Chicago: University of Chicago Press for National Bureau of Economic Research.

Musacchio, Aldo, and Ian Read. 2007. "Bankers, Industrialists, and Their Cliques: Elite Networks in Mexico and Brazil during Early Industrialization." Enterprise and Society 8:842-80.

Nathans, Benjamin. 2002. Beyond the Pale: The Jewish Encounter with Late Imperial Russia. Berkeley and Los Angeles: University of California Press.

North, Douglass C. 1981. Structure and Change in Economic History. New York: Norton.

Owen, Thomas C. 1981. Capitalism and Politics in Russia: A Social History of the Moscow Merchants, 1855-1905. Cambridge: Cambridge University Press.

- 1983. "Entrepreneurship and the Structure of Enterprise in Russia, 18001880." Pp. 59-83 in Entrepreneurship in Imperial Russia and the Soviet Union, edited by Gregory Guroff and Fred V. Carstensen. Princeton, N.J.: Princeton University Press.

- 1991a. The Corporation under Russian Law, 1800-1917: A Study in Tsarist Economic Policy. Cambridge: Cambridge University Press.

— 1991b. "Impediments to a Bourgeois Consciousness in Russia, 1880-1905: The Estate Structure, Ethnic Diversity, and Economic Regionalism.” Pp. 75-89 in Between Tsar and People, edited by Edith W. Clowes, Samuel D. Kassow, and James L. West. Princeton, N.J.: Princeton University Press.

1992. RUSCORP: A Database of Corporations in the Russian Empire, 17001914. 3d release. Ann Arbor, MI: Inter-University Consortium for Political and Social Research.

- 2005. Dilemmas of Russian Capitalism: Fedor Chizhov and Corporate Enterprise in the Railroad Age. Cambridge, Mass.: Harvard University Press.

Podolny, Joel M. 2005. Status Signals: A Sociological Study of Market Competition. Princeton, N.J.: Princeton University Press.

Powell, Walter W., Douglas R. White, Kenneth W. Koput, and Jason Owen-Smith. 2005. "Network Dynamics and Field Evolution: The Growth of Interorganizational Collaboration in the Life Sciences." American Journal of Sociology 110:1132-1205.

Rieber, Alfred J. 1982. Merchants and Entrepreneurs in Imperial Russia. Chapel Hill: University of North Carolina Press. 


\section{American Journal of Sociology}

Rogger, Hans. 1986. Jewish Policies and Right-Wing Politics in Imperial Russia. Berkeley and Los Angeles: University of California Press.

Ruckman, Jo Ann. 1984. The Moscow Business Elite: A Social and Cultural Portrait of Two Generations, 1840-1905. DeKalb: Northern Illinois University Press.

Ruef, Martin, Howard E. Aldrich, and Nancy M. Carter. 2003. "The Structure of Founding Teams: Homophily, Strong Ties, and Isolation among U.S. Entrepreneurs.” American Sociological Review 68:195-222.

Safford, Sean. 2009. Why the Garden Club Couldn't Save Youngstown: The Transformation of the Rust Belt. Cambridge, Mass.: Harvard University Press.

Strumilin, Stanislav Gustavovich. 1966. Ocherki ekonomicheskoi istorii Rossii i SSSR [Studies on Russian and Soviet economic history]. Moscow: Nauka.

Stuart, Toby, Ha Hoang, and Ralph C. Hybels. 1999. "Interorganizational Endorsements and the Performance of Entrepreneurial Ventures." Administrative Science Quarterly 44:315-49.

Uzzi, Brian, and Jarrett Spiro. 2005. "Collaboration and Creativity: The Small World Problem." American Journal of Sociology 111:447-504.

Von Laue, Theodore H. 1963. Sergei Witte and the Industrialization of Russia. New York: Columbia University Press.

Weeks, Theodore R. 1996. Nation and State in Late Imperial Russia: Nationalism and Russification on the Western Frontier, 1863-1914. DeKalb: Northern Illinois University Press.

Weingast, Barry R. 1997. "The Political Foundations of Democracy and the Rule of Law." American Political Science Review 91:245-63.

Wimmer, Andreas, and Kevin Lewis. 2010. "Beyond and Below Racial Homophily: ERG Models of a Friendship Network Documented on Facebook." American Journal of Sociology 116:583-642. 